\title{
Influence of Subunit Composition on Desensitization of Neuronal Acetylcholine Receptors at Low Concentrations of Nicotine
}

\author{
Catherine P. Fenster, ${ }^{1,2}$ M. Felicia Rains, ${ }^{1}$ Brett Noerager, ${ }^{2}$ Michael W. Quick, ${ }^{1,2}$ and Robin A. J. Lester ${ }^{1,2}$ \\ Departments of ${ }^{1}$ Neurobiology and ${ }^{2}$ Physiology and Biophysics, University of Alabama at Birmingham, Birmingham, \\ Alabama 35294
}

The influence of $\alpha$ and $\beta$ subunits on the properties of nicotineinduced activation and desensitization of neuronal nicotinic acetylcholine receptors (nAChRs) expressed in Xenopus oocytes was examined. Receptors containing $\alpha 4$ subunits were more sensitive to activation by nicotine than $\alpha 3$-containing receptors. At low concentrations of nicotine, nAChRs containing $\beta 2$ subunits reached near-maximal desensitization more rapidly than $\beta 4$-containing receptors. The concentration of nicotine producing half-maximal desensitization was influenced by the particular $\alpha$ subunit expressed; similar to results for activation, $\alpha 4$-containing receptors were more sensitive to desensitizing levels of nicotine than $\alpha 3$-containing receptors. The $\alpha$ subunit also influenced the rate of recovery from desensitization; this rate was approximately inversely proportional to the apparent nicotine affinity for the desensitized state. The homomeric $\alpha 7$ receptor showed the lowest sensitivity to nicotine for both activation and desensitization; $\alpha 7$ nAChRs also demonstrated the fastest desensitization kinetics. These subunitdependent properties remained in the presence of external calcium, although subtle, receptor subtype-specific effects on both the apparent affinities for activation and desensitization and the desensitization kinetics were noted. These data imply that the subunit composition of various nAChRs determines the degree to which receptors are desensitized and/or activated by tobacco-related levels of nicotine. The subtype-specific balance between receptor activation and desensitization should be considered important when the cellular and behavioral actions of nicotine are interpreted.

Key words: nicotinic receptor subtypes; nicotine addiction; ion channel; CNS; desensitization; regulation; Xenopus oocytes; calcium ions; synaptic transmission
Neuronal nicotinic receptors (nAChRs) are a functionally diverse group of ligand-gated ion channels formed from the pentameric arrangement of one or more individual subunits (Couturier et al., 1990; Anand et al., 1991; Cooper et al., 1991; Luetje and Patrick, 1991). The existence of multiple subtypes (Role, 1992), their nonuniform distribution within the CNS (Duvoisin et al., 1989; Wada et al., 1989; Morris et al., 1990; Whiting et al., 1991; DineleyMiller and Patrick, 1992; Seguela et al., 1993), and their localization to both pre- and postsynaptic zones (Clark, 1993; McGehee and Role, 1996; Role and Berg, 1996; Wonnacott, 1997) imply diverse functions of nAChRs and suggest that several mechanisms are involved in the behaviorally important actions of nicotine.

At a minimum, any cellular and molecular theory of nicotine dependency must take into account that nAChRs can be both activated and desensitized by nicotine (Katz and Thesleff, 1957). Much evidence supports the idea that each of these receptor states is critical in addiction (Stolerman and Shoaib, 1991; Dani and Heinemann, 1996). Because these receptor states vary according to subunit composition (Cachelin and Jaggi, 1991; Gross et al., 1991; Hsu et al., 1995; Vibat et al., 1995), subtypes of nAChRs may be involved differentially in the acute and chronic

Received Dec. 30, 1996; revised April 18, 1997; accepted May 19, 1997.

This work was supported by United States Public Health Service (USPHS) National Institute of Neurological Disorders and Stroke Grant R29 NS31669 (R.A.J.L.), USPHS National Cancer Institute Grant CA13148 (M.W.Q.), and W. M. Keck Foundation Grant 931360. We thank Dr. David S. Weiss for helpful discussions and comments on this manuscript.

Correspondence should be addressed to Dr. Robin A. J. Lester, Department of Neurobiology, CIRC Room 560, University of Alabama at Birmingham, 1719 Sixth Avenue South, Birmingham, AL 35294-0021.

Copyright (C) 1997 Society for Neuroscience $0270-6474 / 97 / 175747-13 \$ 05.00 / 0$ effects of nicotine and their associated cellular compensatory events (Balfour, 1994). These include subtype-specific increases in receptor number within various brain regions (Marks et al., 1992). Moreover, the extent to which nAChR subtypes are activated and desensitized by nicotine could determine whether specific receptor subtypes are functionally up- (Rowell and Wonnacott, 1990; Gopalakrishnan et al., 1996) or downregulated (Marks et al., 1993) during chronic agonist exposure (Hsu et al., 1995).

Although the actual subunit composition of native CNS nAChRs is unknown, many expressed receptor subtypes (Whiting and Lindstrom, 1988; Flores et al., 1992; Anand et al., 1993) share characteristics of CNS nAChRs. Thus, understanding the influences of different subunits on receptor function has value both for determining dominant subunits in native receptors and for predicting the effects of nicotine on nAChRs composed of particular subunits. Previous studies have addressed how subunit composition affects the time course of desensitization and the agonist potency for activation (Cachelin and Jaggi, 1991; Gross et al., 1991; Luetje and Patrick, 1991; Cohen et al., 1995; Hsu et al., 1995; Vibat et al., 1995). However, many of these studies used acetylcholine as the principal agonist. Because agonists can affect desensitization differentially, it is not possible to predict accurately how nicotine will interact with desensitized states of nAChRs. Moreover, except for one report (Hsu et al., 1995), desensitization has not been characterized using low, tobaccorelated concentrations of nicotine (Benowitz et al., 1989). In the present study we evaluate the action of low concentrations of nicotine on both activation and desensitization of a number of nAChRs expressed in Xenopus oocytes and examine the contribution of both $\alpha$ and $\beta$ subunits to these processes. 


\section{MATERIALS AND METHODS}

Xenopus oocyte preparation and $c R N A$ injection. Procedures for preparation of oocytes have been described in detail elsewhere (Quick and Lester, 1994). Briefly, oocytes were defolliculated and maintained at $18^{\circ} \mathrm{C}$ in incubation medium containing ND96 $(96 \mathrm{~mm} \mathrm{NaCl}, 2 \mathrm{~mm} \mathrm{KCl}$, $1 \mathrm{mM} \mathrm{MgCl}_{2}$, and $5 \mathrm{~mm} \mathrm{HEPES,} \mathrm{pH} \mathrm{7.4),} 1.8$ or $3.6 \mathrm{mM} \mathrm{CaCl}_{2}, 50 \mu \mathrm{g} / \mathrm{ml}$ gentamycin, and 5\% horse serum. Subunit cRNAs were synthesized in vitro (Machine Message; Ambion, Austin, TX) from linearized plasmid templates of rat cDNA clones. Oocytes were injected with between 5 and $25 \mathrm{ng} /$ subunit per oocyte; $\alpha$ and $\beta$ subunit cRNAs were injected in 1:1 ratios, although in some experiments in which $\alpha 3 \beta 4$ receptors were examined, cRNAs ratios of 10:1 $\alpha 3: \beta 4$ and 1:10 $\alpha 3: \beta 4$ were injected. All salts and drugs were obtained from Sigma (St. Louis, MO).

Electrophysiology. Whole-cell currents were measured at room temperature $\left(20-25^{\circ} \mathrm{C}\right), 24-96 \mathrm{hr}$ postinjection, with a Geneclamp 500 amplifier (Axon Instruments, Foster City, CA) in a standard two-microelectrode voltage-clamp configuration. Electrodes were filled with $3 \mathrm{M} \mathrm{KCl}$ and had resistances of $\sim 0.5-2 \mathrm{M} \Omega$. Oocytes were clamped between -40 and -60 $\mathrm{mV}$ and superfused continuously in calcium-free ND96 (i.e., nominally calcium-free solution) or in the presence of $3.6 \mathrm{~mm}$ calcium (i.e., calciumcontaining solutions). This concentration of calcium is in the middle of the range for potentiation of nAChRs responses (Mulle et al., 1992b; Vernino et al., 1992). For comparison, the effects of 1.8 and $3.6 \mathrm{~mm}$ calcium were examined on $\alpha 7$ receptors. All drugs were applied in these solutions. (-)-Nicotine tartrate (nicotine) and acetylcholine chloride (acetylcholine) were prepared from frozen stock solutions (100 mM). Atropine $(1 \mu \mathrm{M})$ was included in the superfusion solution to block endogenous muscarinic responses. All currents were recorded either on a chart recorder and/or on an 80486-based personal computer with AxoScope software (Axon Instruments) after 50-100 Hz low-pass filtering at a digitization frequency of $200 \mathrm{~Hz}$. For slowly desensitizing responses, peak currents were assessed on-line from the digital readout of the amplifier and/or off-line with AxoScope software.

Peak currents at $\mathrm{EC}_{50}$ concentrations were typically in the range of 100 $\mathrm{nA}-2 \mu \mathrm{A}$. Currents as small as $5 \mathrm{nA}$ could be measured, although for accuracy only currents above $20 \mathrm{nA}$ were included in the desensitization measurements. Concentration-response curves were fit with logistic expressions to estimate the $\mathrm{EC}_{50}$ (activation) and $\mathrm{IC}_{50}$ (desensitization). Single and/or double exponential fits of the data were used to compare the time courses of desensitization and recovery. Exponential curves were fit either to the desensitizing phase of the nAChR responses or to the time course of desensitization development as assessed from the depression of test pulses applied during incubation with nicotine. In both cases exponentials were constrained not to fall below zero current. For some nAChR subtypes, recovery from desensitization could be slow ( $>1$ $\mathrm{hr}$ ) and often was incomplete before the recording became unstable. For these data the exponential fits were constrained to allow full recovery back to control values.

Solutions were gravity-fed via a six-way manual valve (Rainin Instruments, Woburn, MA) to the oocyte in the recording chamber; some solution mixing occurred in the dead space between the valve and the chamber. To estimate the effect of dead space on the agonist application, we calculated the solution exchange rate from the time course of inhibition of the current induced by nicotine $(5 \mu \mathrm{M})$ through $\beta 4$ subunitcontaining receptors during a step from medium containing $96 \mathrm{~mm} \mathrm{NaCl}$ to one containing $48 \mathrm{~mm} \mathrm{NaCl}$ ( $96 \mathrm{~mm}$ sucrose was used to restore osmolality). The time constant for the exchange, obtained from a single exponential fit, was $1.3 \pm 0.3 \mathrm{sec}(10$ observations from five different oocytes). Thus, solution exchange was complete within $\sim 5 \mathrm{sec}$. Because of this noninstantaneous exchange, at high agonist concentrations and in particular for $\alpha 7 \mathrm{nAChRs}$ that desensitize very rapidly, true peak currents are underestimated. This may result in an overestimation of the $\mathrm{EC}_{50}$ for activation and a smaller Hill coefficient. Although this is a potential problem in certain types of analyses, in the present study we were concerned for the most part with activation and desensitization at relatively low agonist concentrations in which the influence of exchange rate is less critical. All data are expressed as the mean \pm SEM. For statistical comparisons of concentration-response curves, $t$ tests were performed on the regression coefficients, estimated by using the method of probits (Finney, 1971). For statistical comparisons of mean data, weighted means $t$ tests were performed for all unpaired comparisons.

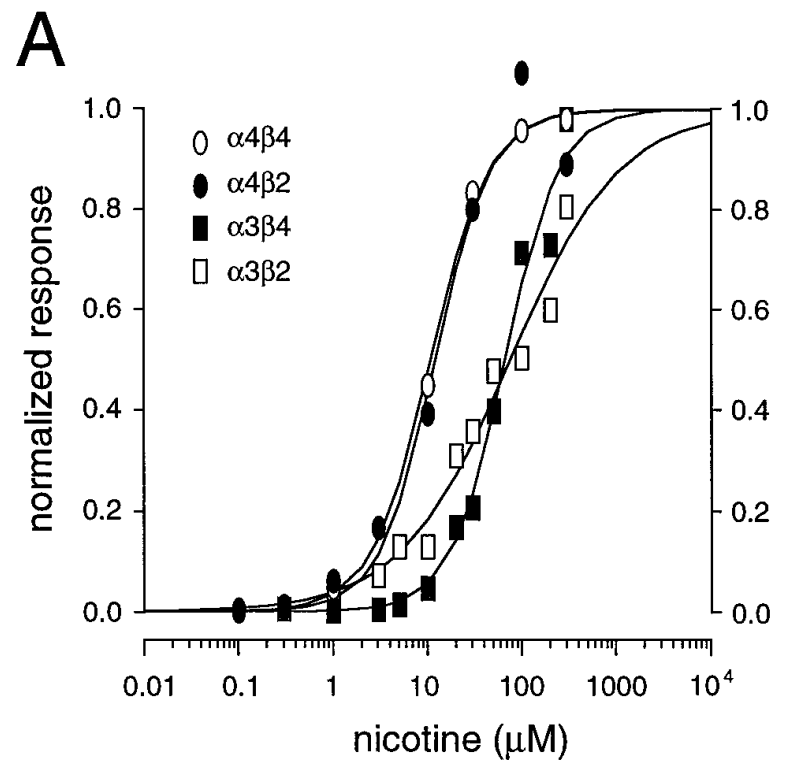

B $\alpha 3 \beta 4$
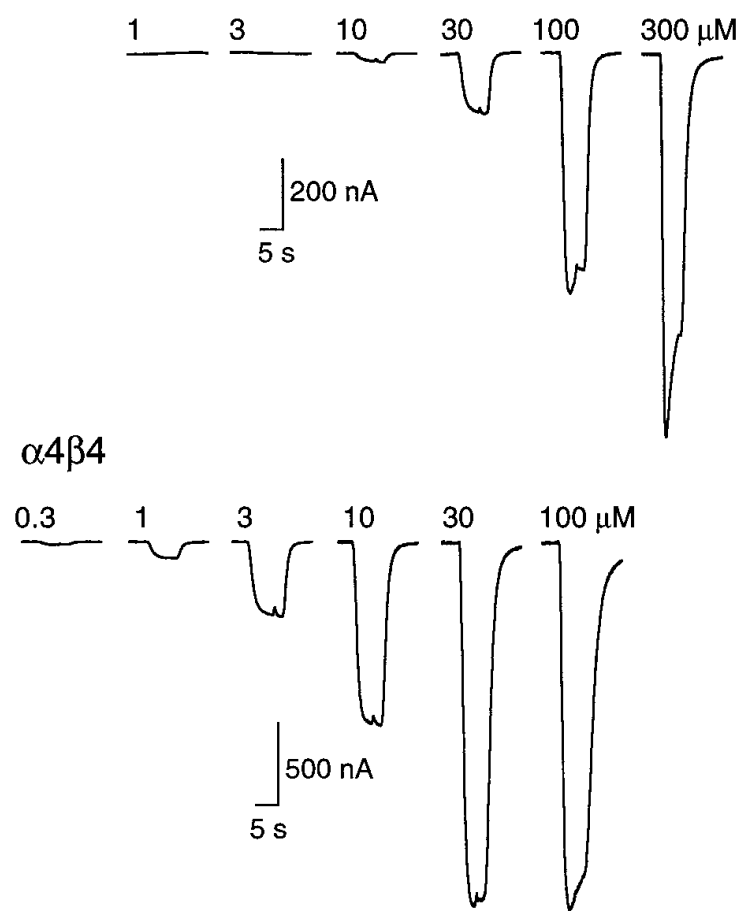

Figure 1. $\alpha 4$ subunits confer high apparent affinity on nAChRs. $A$, Concentration-response curves were constructed by measuring the peak current induced in response to brief $(5-10 \mathrm{sec})$ applications of nicotine $(100 \mathrm{nM}-300 \mu \mathrm{M})$. The peak responses are plotted with respect to agonist concentration for four subtypes of nAChRs $(\alpha 3 \beta 4, \alpha 3 \beta 2, \alpha 4 \beta 4$, and $\alpha 4 \beta 2$ ). For each subtype all responses were normalized to a response near the half-maximal concentration $\left(\mathrm{EC}_{50}\right)$. Each point represents one to eight separate measurements. The solid lines are logistic fits to the data. The calculated $\mathrm{EC}_{50}$ values and the Hill coefficients were, respectively, 65 $\mu \mathrm{M}$ and $1.5(\alpha 3 \beta 4), 75 \mu \mathrm{M}$ and $0.7(\alpha 3 \beta 2), 11 \mu \mathrm{M}$ and $1.4(\alpha 4 \beta 4)$, and 12 $\mu \mathrm{M}$ and $1.5(\alpha 4 \beta 2)$. B, Representative current responses for a series of nicotine concentrations applied to two different oocytes expressing either $\alpha 3 \beta 4$ receptors (top traces) or $\alpha 4 \beta 4$ receptors (bottom traces). All data shown in this figure were obtained in calcium-free conditions. 
Table 1. Subunit-specific properties of nAChRs

\begin{tabular}{|c|c|c|c|c|c|c|c|}
\hline \multirow[b]{2}{*}{ Subtype } & \multicolumn{2}{|c|}{$\begin{array}{l}\mathrm{EC}_{50}{ }^{a} \\
(\mu \mathrm{M})\end{array}$} & \multirow{2}{*}{$\begin{array}{l}\mathrm{IC}_{50}{ }^{b} \\
(\mu \mathrm{M}) \\
\pm \mathrm{Ca}\end{array}$} & \multirow{2}{*}{$\begin{array}{l}\text { Desensitization } \\
\text { at } 500 \mathrm{~nm}(\%) \\
\pm \mathrm{Ca}\end{array}$} & \multicolumn{2}{|c|}{$\begin{array}{l}\text { Desensitization time course }{ }^{c} \\
\left(\tau_{\mathrm{d}} ; \mathrm{min}\right)\end{array}$} & \multirow{2}{*}{$\begin{array}{l}\text { Desensitization recovery }{ }^{d} \\
(\tau ; \mathrm{min}) \\
\pm \mathrm{Ca}\end{array}$} \\
\hline & $+\mathrm{Ca}$ & $-\mathrm{Ca}$ & & & $+\mathrm{Ca}$ & $-\mathrm{Ca}$ & \\
\hline$\alpha 3 \beta 4$ & 62 & 65 & 1.15 & 39 & $32.5 \pm 2.5(3)$ & $36.8 \pm 4.8(7)$ & $42.6 \pm 5.5(4)$ \\
\hline$\alpha 4 \beta 4$ & 9 & 11 & 0.042 & 87 & $35.5^{*} \pm 3.2(5)$ & $16.2 \pm 2.8(3)$ & $413.8^{f} \pm 305.5(2)$ \\
\hline$\alpha 3 \beta 2$ & 123 & 75 & 0.33 & 47 & $\approx 5(3)^{e}$ & $3.9 \pm 2.1(4)$ & $11.7 \pm 4.1(2)$ \\
\hline$\alpha 4 \beta 2$ & 15 & 12 & 0.061 & 71 & $3.7 \pm 0.9(4)$ & $2.7 \pm 0.3(2)$ & $86.9 \pm 64.7(4)$ \\
\hline \multirow[t]{2}{*}{$\alpha 7$} & $90^{*}$ & 234 & $6.2(-\mathrm{Ca})$ & $1(-\mathrm{Ca})$ & $0.5 \pm 0.03(3)$ & $1.9 \pm 0.5(4)$ & $1.9 \pm 0.5(5)$ \\
\hline & & & $1.3^{*}(+\mathrm{Ca})$ & $12(+\mathrm{Ca})$ & & & \\
\hline
\end{tabular}

\footnotetext{
${ }^{a} \mathrm{EC}_{50}$ calculated from the activation concentration-response curve in calcium-containing $(+\mathrm{Ca})$ and calcium-free $(-\mathrm{Ca}) \mathrm{media}$.

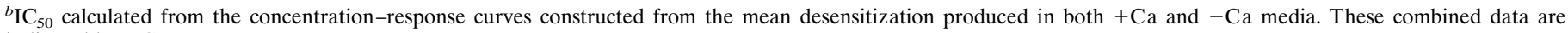
indicated by $\pm \mathrm{Ca}$.

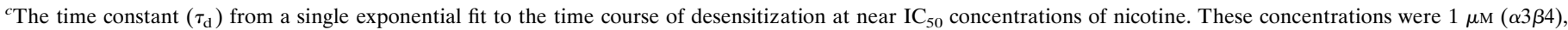
$100 \mathrm{~nm}(\alpha 4 \beta 4), 300 \mathrm{nM}(\alpha 3 \beta 2), 300 \mathrm{~nm}(\alpha 4 \beta 2), 10 \mu \mathrm{M}(-\mathrm{Ca}, \alpha 7)$, and $3 \mu \mathrm{M}(+\mathrm{Ca}, \alpha 7)$. The number of measurements is indicated in parentheses.

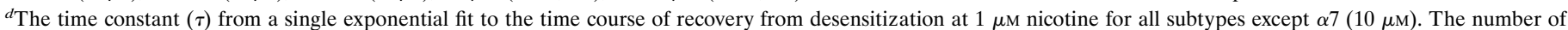
measurements is indicated in parentheses. In the majority of experiments, the exponential was fit by assuming full recovery to control values.

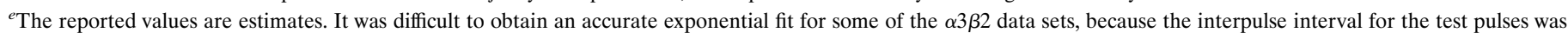
large (5-10 $\mathrm{min})$ and desensitization mainly was complete by the time of the first test pulse.

${ }^{f}$ Two additional oocytes expressing $\alpha 4 \beta 4$ receptors showed no recovery after $20-30$ min wash.

*Indicates significance $(p<0.05)$, as compared with data obtained in calcium-free media.
}

\section{RESULTS}

\section{Potency of nicotine for activation of nAChRs}

The differential sensitivity of nicotine in activating various expressed receptors (Luetje and Patrick, 1991) implies that nicotine is not equipotent at all nAChRs. Nicotine-induced concentration-response relationships for four different expressed nAChRs ( $\alpha 3 \beta 4, \alpha 3 \beta 2, \alpha 4 \beta 4$, and $\alpha 4 \beta 2$ ) confirm this hypothesis (Fig. 1). Logistic fits to these concentration-response curves estimate $\mathrm{EC}_{50}$ values that can be divided into two groups (Table 2): receptors containing $\alpha 4$ subunits have lower $\mathrm{EC}_{50}$ values than those containing $\alpha 3$ subunits $(t=13.27$; $p<0.01)$, implying that $\alpha 4$ subunits confer a higher apparent nicotine affinity. Because of the high permeability of various neuronal nAChRs to calcium (Mulle et al., 1992a; Vernino et al., 1992; Seguela et al., 1993; Rathouz and Berg, 1994) and the potential contamination of the measured currents with the activation of oocyte endogenous calcium-dependent $\mathrm{Cl}^{-}$currents (Vernino et al., 1992), the above series of experiments was conducted in nominally calcium-free media. Physiologically relevant levels of calcium can, however, regulate $\mathrm{nAChR}$ activation, an effect that may result, in part, from changes in the affinity of nAChRs for agonist (Mulle et al., 1992b; Vernino et al., 1992; Galzi et al., 1996). To ascertain that the observed differences in the $\mathrm{nAChR}$ concentration-response relationships in calcium-free solutions were physiologically important, we repeated the experiments in calcium-containing media. The addition of calcium produced insignificant changes in $\mathrm{EC}_{50}$ values $(t=0.35 ; p>0.05)$ and did not alter the order of potency of nicotine for the various $\mathrm{nAChR}$ subtypes (Table 1 ).

The much higher apparent nicotine affinity of $\alpha 4$-containing subtypes, as compared with $\alpha 3$-containing subtypes, is consistent with previous reports for heterologously expressed nAChRs from both chick (Hussy et al., 1994) and rat (Vibat et al., 1995). For $\alpha 3$ subunit-containing receptors, our estimated $\mathrm{EC}_{50}$ values for nicotine were comparable to previously published data (for review, see Role, 1992; McGehee and Role, 1995). Little or no comparable data exist for $\alpha 4 \beta 4$ receptors (Role, 1992). Our data for the $\alpha 4 \beta 2$ receptor predict a lower apparent nicotine affinity $(15 \mu \mathrm{M}$, calcium-containing solutions) than reports of heterologously expressed $\alpha 4 \beta 2 \mathrm{nAChRs}$ from chick (0.8 $\mu \mathrm{M}$; Bertrand et al., 1990), rat (0.3 $\mu \mathrm{M}$; Vibat et al., 1995), and human (1.6 $\mu \mathrm{M}$; Buisson et al., 1996).

\section{Different time courses of desensitization of nAChR subtypes}

Previous data show that nAChRs composed of different subunits desensitize with different time courses in response to various nicotinic agonists (Cachelin and Jaggi, 1991; Gross et al., 1991, 1995; Vibat et al., 1995). We have extended these findings, using nicotine as the agonist. Figure $2 A$ shows representative responses of oocytes expressing four different $\mathrm{nAChR}$ subtypes to a $3 \mathrm{~min}$ application of nicotine at near half-maximal concentrations (see Fig. 1) in the presence of external calcium. Receptors containing $\beta 4$ subunits desensitize slower than those containing $\beta 2$ subunits $(t=6.2 ; p<0.05)$. In most experiments the time course of desensitization for receptors containing $\beta 4$ subunits was well described by a single exponential decay. In some oocytes, particularly those with larger peak currents, a faster "desensitizing" component was present in $\alpha 4 \beta 4$-expressing and $\alpha 3 \beta 4$-expressing oocytes (Fig. $2 C$ ). The fast component was calcium-dependent because it was eliminated, for the most part, when the same cells were examined in calcium-free media (Table 2). In contrast, the slower component of desensitization was unaffected by calcium $(t=0.21 ; p>0.05$; Fig. 2B, Table 2$)$. These data are consistent with previous reports in which it was argued that a transient calcium-dependent $\mathrm{Cl}^{-}$current could be activated by certain neuronal nAChRs (Vernino et al., 1992; Seguela et al., 1993). On the other hand, $\beta 2$-containing receptors generally required the sum of two exponentials for a good fit to the data in both the presence and absence of calcium, although the relative amplitude of the fast component was affected significantly by calcium $(t=$ 76.5; $p<0.01$; Fig. 2; Table 2). Thus $\beta 2$-containing $\mathrm{nAChRs}$ have, in addition to a slow component of desensitization, an intrinsic fast desensitization process. Differences in the size of the fast "desensitizing" component of $\alpha 4 \beta 2$ and $\alpha 3 \beta 2$ receptors in calcium-free and calcium-containing medium potentially could reflect differences in the extent of activation of the endogenous $\mathrm{Cl}^{-}$current and/or differential modulation of the fast and slow components by external calcium ions.

Brief agonist applications do not provide sufficient data to 
A

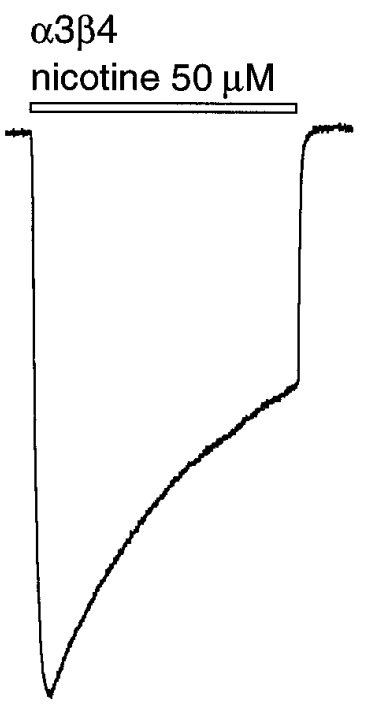

\section{$\alpha 4 \beta 4$ nicotine $10 \mu \mathrm{M}$}

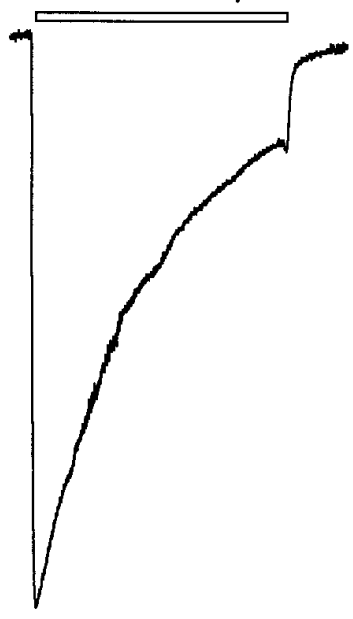

$\alpha 3 \beta 2$ nicotine $50 \mu \mathrm{M}$

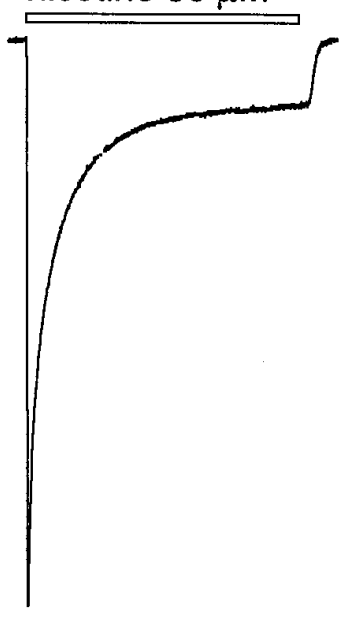

$\alpha 4 \beta 2$

$$
\text { nicotine } 10 \mu \mathrm{M}
$$

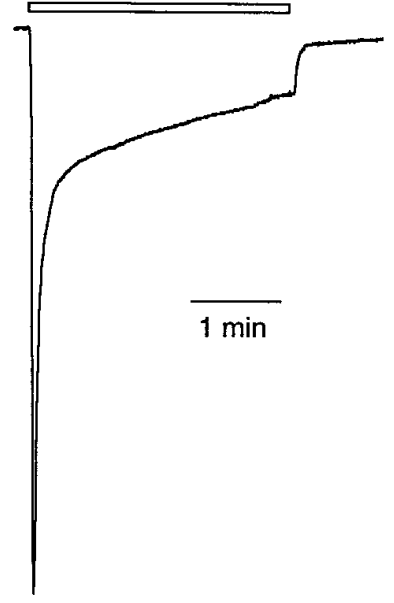

B

$\alpha 4 \beta 4$

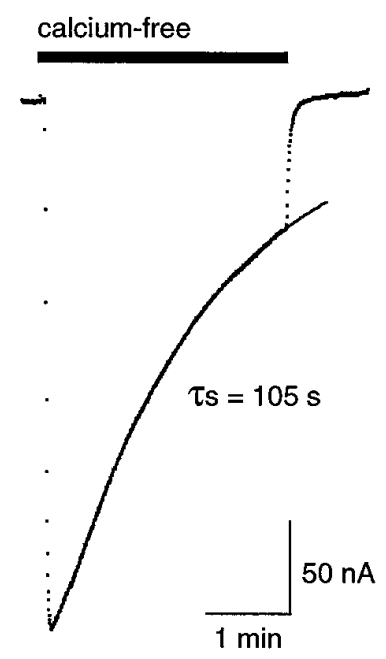

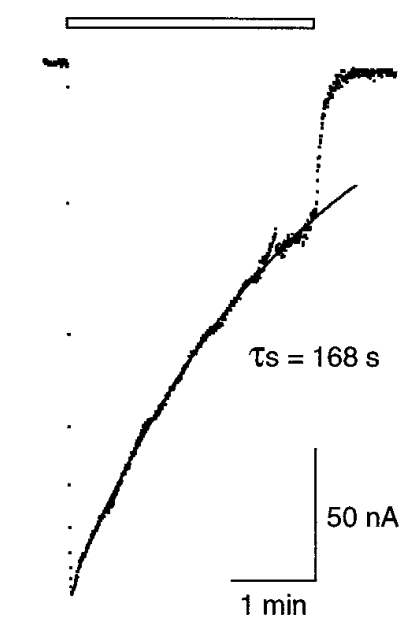

C

$\alpha 3 \beta 4$

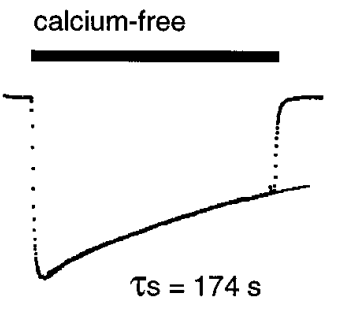

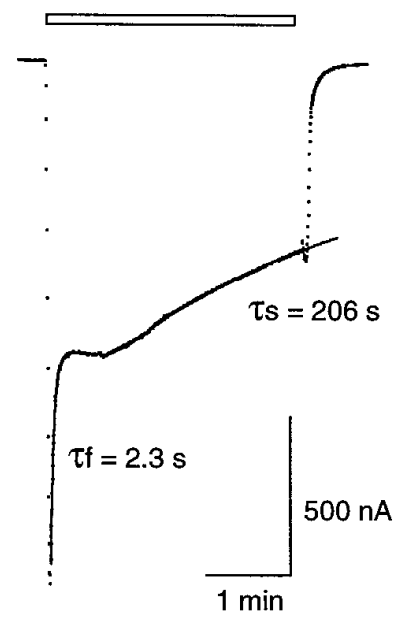

Figure 2. The time course of desensitization varies with nAChR subtype. $A$, Responses to brief ( 3 min) applications of nicotine at near EC $\mathrm{E}_{50}$ concentrations in calcium-containing media for oocytes injected with different subunit combinations. For comparison, the responses are normalized to their peaks. The time course of desensitization for responses obtained from oocytes expressing $\beta 4$-containing receptors (left two traces) were well described by a single exponential component. For $\beta 2$-containing receptors (right two traces), the decay phase was well described by the sum of two exponentials. $B$, Responses to 3 min applications of nicotine in calcium-free (left trace) and calcium-containing (right trace) media for an oocyte expressing $\alpha 4 \beta 4$ receptors. The traces are normalized to the peak currents. The solid lines are single exponential functions fit to the desensitizing phase of the responses, and their associated time constants $\left(\tau_{\mathrm{s}}\right)$ are shown. $C$, Responses to 3 min applications of nicotine in calcium-free (left trace) and calcium-containing (right trace) media for an oocyte expressing $\alpha 3 \beta 4$ receptors. The solid lines are single exponential functions fit to the desensitizing phase of the responses. In calcium-containing media the data were fit with two separate single exponentials, designated $\tau_{\mathrm{f}}$ and $\tau_{\mathrm{s}}$. The exponential functions contained a steady-state component, which was constrained not to fall below baseline current. The final steady-state values were generally in the range of $0-20 \%$ peak current.

characterize receptor desensitization fully (Katz and Thesleff, 1957; Feltz and Trautman, 1982). Moreover, the desensitization resulting from long applications of nanomolar concentrations of nicotine may reveal receptor subtype differences that are related more closely to mechanisms underlying nicotine dependency (Stolerman and Shoaib, 1991; Dani and Heinemann, 1996). With this in mind, we examined the subunit dependence of nAChR desensitization induced by low levels of nicotine. Because it is not possible to measure desensitization directly from the very small currents produced by such low agonist concentrations, desensitization was estimated from the nicotine-induced reduction in the current elicited by a brief $(5-10 \mathrm{sec})$ test pulse of acetylcholine (ACh) near the half-maximal concentration for each receptor (Feltz and Trautman, 1982). The ACh test pulses were applied at sufficient time intervals (2-10 min, based on the particular subunit combination) so as not to induce any additional desensitization. 
Table 2. Calcium dependence of nAChR desensitization

\begin{tabular}{|c|c|c|c|c|c|c|c|c|}
\hline \multirow[b]{2}{*}{ Subtype } & \multicolumn{2}{|l|}{$\tau_{\text {slow }}(\mathrm{sec})$} & \multicolumn{2}{|l|}{$\underline{\tau_{\text {fast }}(\mathrm{sec})}$} & \multicolumn{2}{|c|}{ Fast component $(\%)$} & \multicolumn{2}{|c|}{$\begin{array}{l}\text { Fraction of cells with } \\
\text { fast component }\end{array}$} \\
\hline & $+\mathrm{Ca}$ & $-\mathrm{Ca}$ & $+\mathrm{Ca}$ & $-\mathrm{Ca}$ & $+\mathrm{Ca}$ & $-\mathrm{Ca}^{a}$ & $+\mathrm{Ca}$ & $-\mathrm{Ca}$ \\
\hline$\alpha 4 \beta 4$ & $129.8 \pm 20.2$ & $123.7 \pm 9.9$ & $3.2 \pm 1.1$ & $\mathrm{~N} / \mathrm{A}$ & $13.6 \pm 9.2$ & N/A & $2 / 5$ & $0 / 5$ \\
\hline$\alpha 4 \beta 2$ & $90.7 \pm 5.9$ & $102.5 \pm 20.0$ & $5.4 \pm 1.5$ & $7.4 \pm 1.4$ & $40.3^{*} \pm 3.2$ & $11.3 \pm 6.1$ & $3 / 3$ & $2 / 3$ \\
\hline$\alpha 3 \beta 4^{b}$ & $204.6 \pm 25.4$ & $147.4 \pm 14.1$ & $3.7^{*} \pm 0.7$ & $11.3 \pm 0.9$ & $21.8 \pm 3.7$ & $18.5 \pm 3.5$ & $6 / 11$ & $2 / 11$ \\
\hline$\alpha 3 \beta 2$ & $279.6 \pm 224.5$ & $66.8 \pm 16.2$ & $8.0 \pm 1.5$ & $11.3 \pm 1.7$ & $46.3^{*} \pm 8.6$ & $66.8 \pm 1.0$ & $4 / 4$ & $4 / 4$ \\
\hline
\end{tabular}

All data were obtained from oocytes that were measured in both calcium-free $(-\mathrm{Ca})$ and calcium-containing $(+\mathrm{Ca})$ media.

${ }^{a}$ The mean percentage of fast component includes only those oocytes that had a measurable fast component.

${ }^{b}$ In some oocytes the two desensitization components were fit separately (see Fig. 2).

*Indicates significance $(p<0.05)$, as compared with data obtained in calcium-free media.

The data were expressed as the fractional test current remaining with respect to the time of nicotine exposure. For those experiments in which nicotine induced some receptor activation, the fractional current remaining was calculated from the sum of both the nicotine- and ACh-induced currents. Estimation of desensitization in this manner leads to an underestimation of the extent of desensitization if the current induced by nicotine is a significant fraction of the total response. Large nicotine-induced currents were apparent only at higher agonist concentrations with certain receptor subtypes (e.g., $\alpha 3 \beta 4$; see Fig. 4). In these cases only, both the rate of desensitization development and the magnitude of desensitization will be underestimated slightly.

As shown in Figure 3, incubation of oocytes with nanomolar concentrations of nicotine (levels that produce little activation of any of the receptor subtypes; see Fig. 1) induces a profound desensitization of nAChRs. Differences in the time course of desensitization for different $\mathrm{nAChR}$ subtypes are immediately apparent and parallel the differences in desensitization observed with brief pulses (see Fig. 2). In our experiments, receptors with $\beta 4$ subunits desensitized more slowly than those containing $\beta 2$ subunits $(t=9.7 ; p<0.05)$, irrespective of the presence or absence of calcium (Fig. 3). For all subunits the time course of desensitization could be described reasonably well by a single exponential fit (although see below), which allowed for a more quantitative comparison of desensitization kinetics. Table 1 shows that at concentrations of nicotine that produced a halfmaximal block (see Fig. 5) the time constant for the development of desensitization varied considerably, from $4 \mathrm{~min}(\alpha 3 \beta 2)$ to 45 $\min (\alpha 3 \beta 4)$.

\section{Potency of nicotine for desensitization of nAChRs}

To compare more quantitatively the nicotine-induced desensitization of nAChR subtypes, we examined desensitization over a range of nicotine concentrations. Because the time course of desensitization development is concentration-dependent (Fig. 4) and subtype-dependent (see Fig. 3), different periods of nicotine incubation were required for each $\mathrm{nAChR}$ subtype to reach near-equilibrium conditions. Figure $4 A$ shows that for the receptor with the slowest desensitization time course, $\alpha 3 \beta 4$, a $60 \mathrm{~min}$ exposure was sufficient to produce $\sim 90 \%$ desensitization even at low nicotine concentrations. Longer incubation times typically were not used to allow time for response recovery and to ensure that recovery reflected reversal of desensitization rather than de novo receptor synthesis (Peng et al., 1994; Hsu et al., 1995). In addition, for receptor subtypes that reached equilibrium faster (e.g., $\alpha 3 \beta 2$ ), nicotine exposure was continued in some cases for up to $30 \mathrm{~min}$ to ensure that a slower component of desensitization was not present. Although we cannot exclude completely the possibility that very slow desensitization components exist, desensitization of these subunits by nicotine is complete, for the most part, within the first hour (see also Hsu et al., 1995).

In theory, other mechanisms distinct from desensitization, such as partial antagonism or channel block by nicotine, could explain the decrease in ACh-induced currents in the presence of nicotine. Partial antagonism seems unlikely, especially for $\beta 4$-containing receptors, because the block developed and recovered slowly. Even at low concentrations a purely competitive nicotine effect would be expected to be instantaneous, for the most part. Because nicotine is not a very efficacious agonist at chick $\alpha 3 \beta 2$ receptors (Wang et al., 1996) and given that this receptor subtype shows a relatively fast nicotine block, partial antagonism remains a possibility; however, nicotine does not seem to act as a partial antagonist at rat $\alpha 3 \beta 2 \mathrm{nAChRs}$ (Hussy et al., 1994). A direct, usedependent channel block by nicotine, although reported for neuronal nicotinic receptors, is also unlikely at such low agonist concentrations (Maconochie and Knight, 1992).

Once the time course of desensitization equilibrium was established, inhibition dose-response curves were constructed from the relative depression of an $\mathrm{ACh}$ test pulse induced during incubation with various nicotine concentrations (Fig. 5). The data were fit to a logistic equation from which the $\mathrm{IC}_{50}$ (half-maximal effective desensitizing concentration) for nicotine was estimated. In the present study we refer to the $\mathrm{IC}_{50}$ as the apparent affinity of nicotine for the desensitized state of the receptor. The receptor subtypes could be divided into two groups, based on these $\mathrm{IC}_{50}$ values. Similar to activation (see Fig. 1), nAChRs expressing $\alpha 4$ subunits had a higher apparent affinity for the desensitized state, as compared with nAChRs containing $\alpha 3$ subunits $(t=5.6 ; p<0.05)$. There is an approximately linear relationship between the halfmaximal concentrations of nicotine for activation and desensitization (Table 1). These data indicate that the time course of desensitization is not a good predictor of nicotine affinity for the desensitized state. For example, $\alpha 4 \beta 4$ receptors, which have a slow desensitization onset, demonstrate the highest apparent nicotine affinity for the desensitized state. On the other hand, $\alpha 3 \beta 2$ receptors, which have a fast onset, have a relatively low apparent desensitization affinity. At the highest concentrations of nicotine tested, all nAChR subtypes except $\alpha 3 \beta 2$ receptors were desensitized completely; $\alpha 3 \beta 2$ receptors were desensitized $\sim 78 \%$ (Fig. 5).

\section{Recovery from desensitization}

After prolonged exposure to nicotine, the different $\mathrm{nAChR}$ subtypes recovered to pre-nicotine exposure values with different rates (Fig. 6). Differences in the time course of recovery from 
A
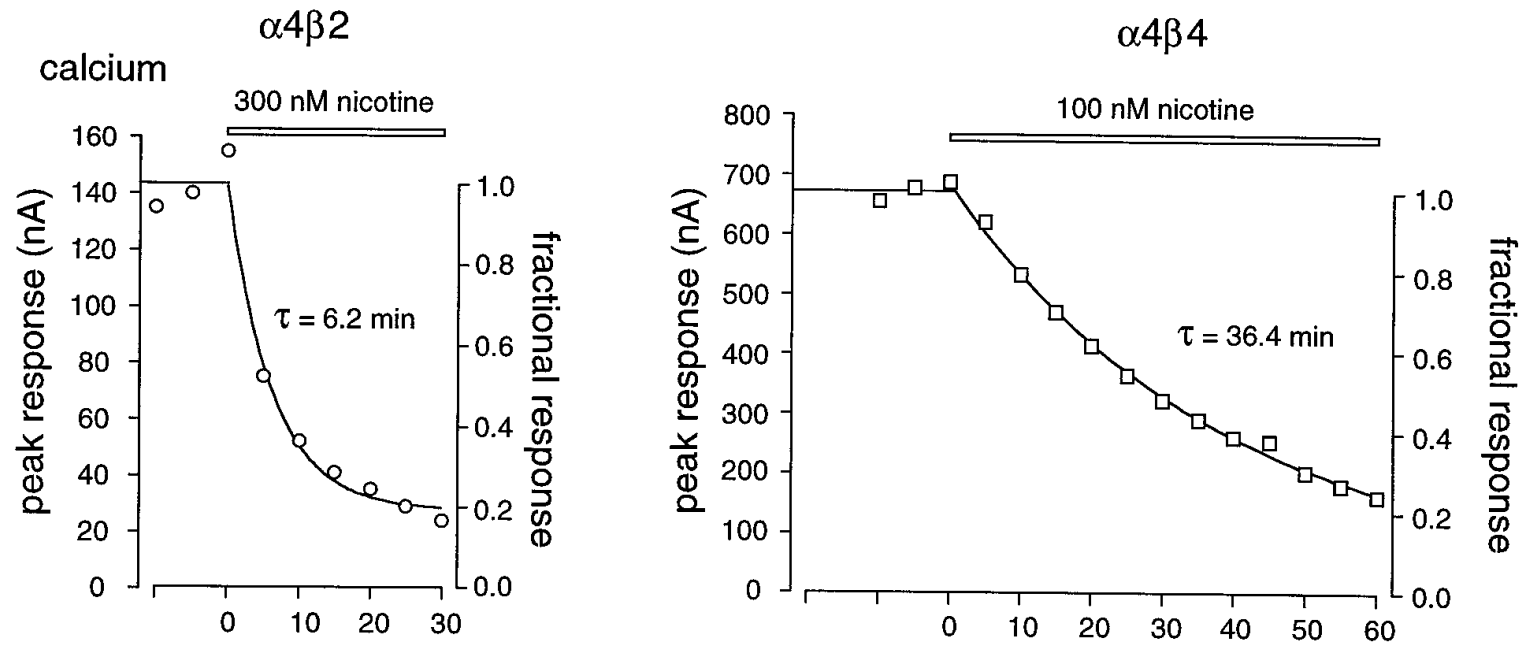

\section{calcium-free}
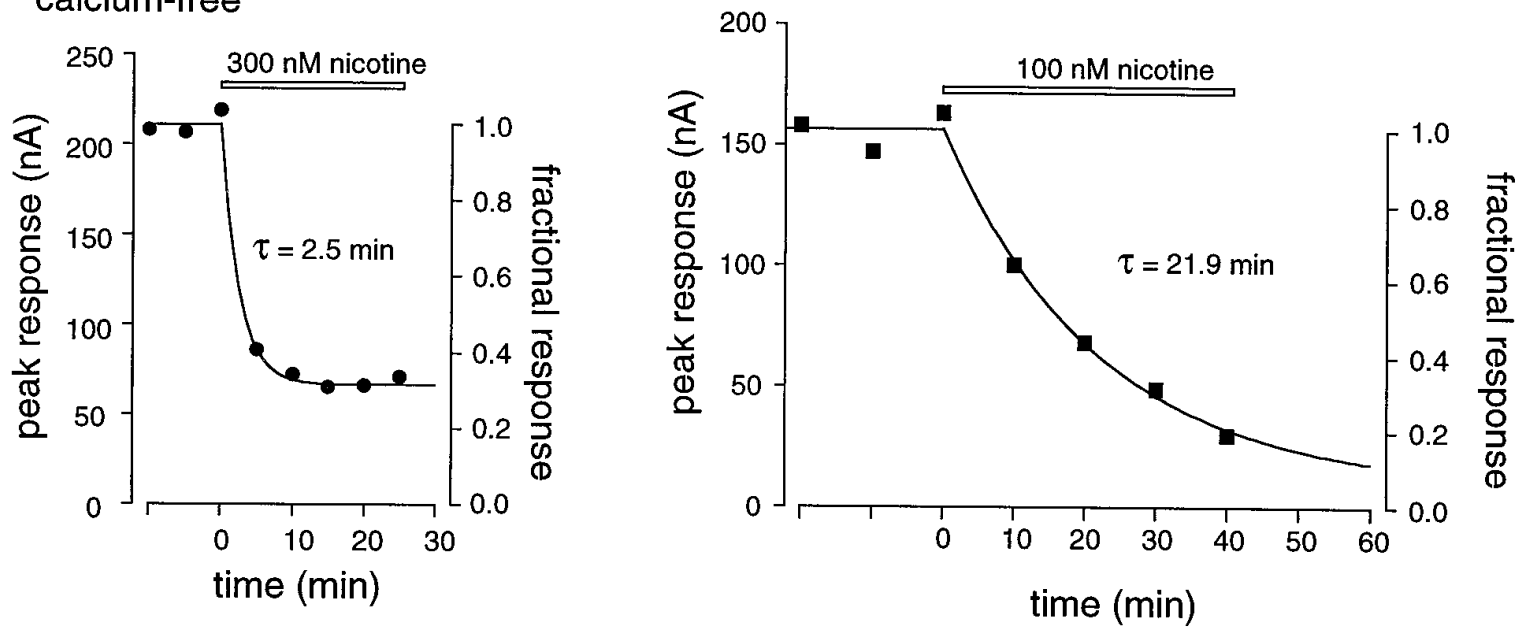

B
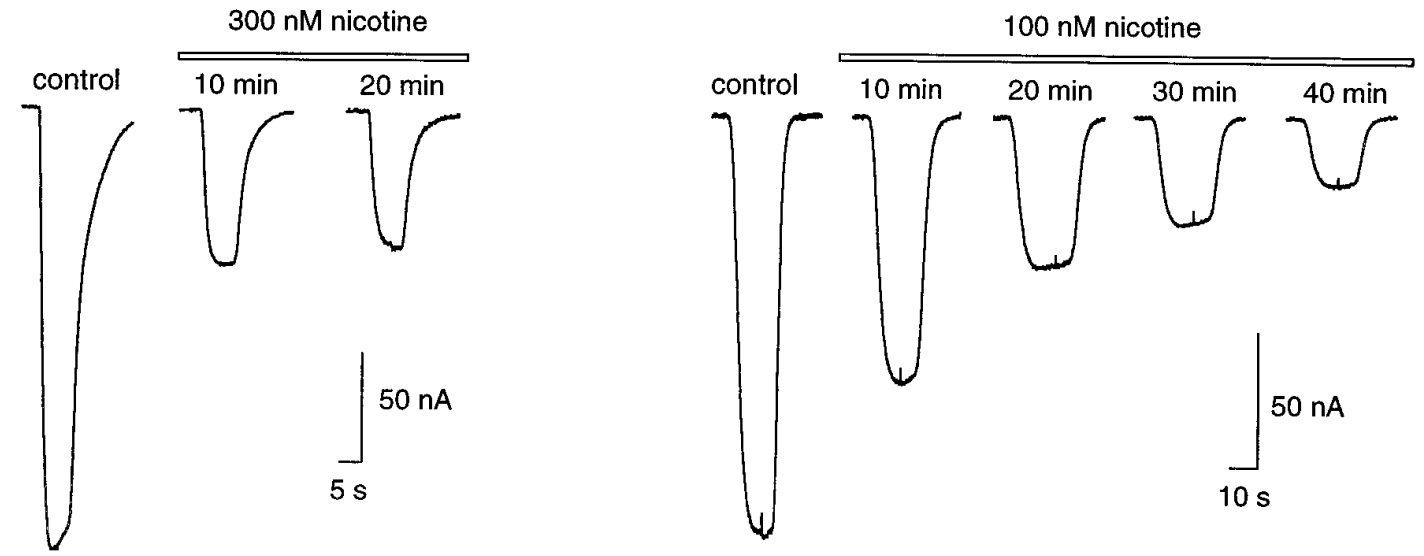

Figure 3. The time course of desensitization is slow in receptors containing $\beta 4$ subunits. $A$, Plot of the peak current amplitudes induced by an ACh test pulse with respect to time before and during continuous perfusion with either 300 or $100 \mathrm{~nm}$ nicotine in oocytes expressing either $\alpha 4 \beta 2$ receptors (left) or $\alpha 4 \beta 4$ (right) receptors, respectively, in calcium-containing (top traces) or calcium-free (bottom traces) media. $\tau$ is the time constant for a single exponential fit to the desensitization time course. $B$, Representative traces of the ACh test pulses before (control) and at the indicated times after incubation with nicotine for individual $\alpha 4 \beta 2$-expressing (bottom left) or $\alpha 4 \beta 4$-expressing (bottom right) oocytes in calcium-free media. 


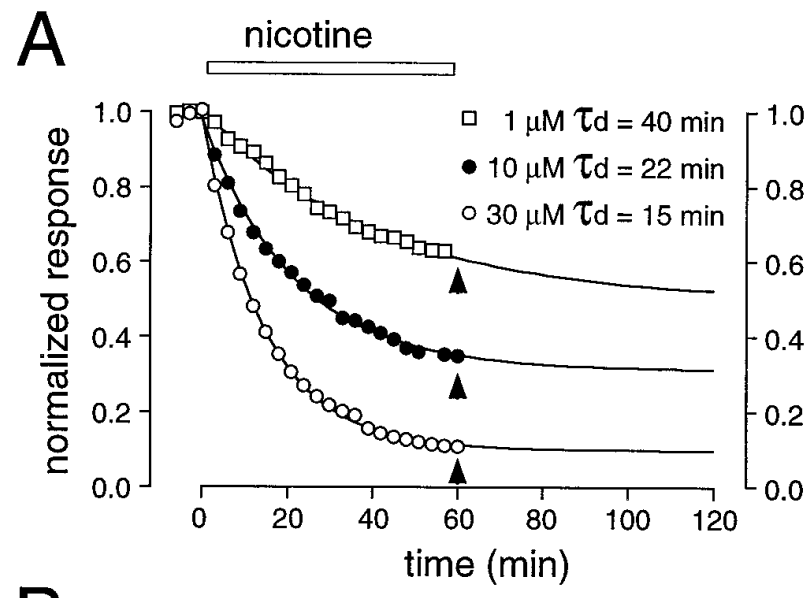

B

\section{$1 \mu \mathrm{M}$ nicotine}

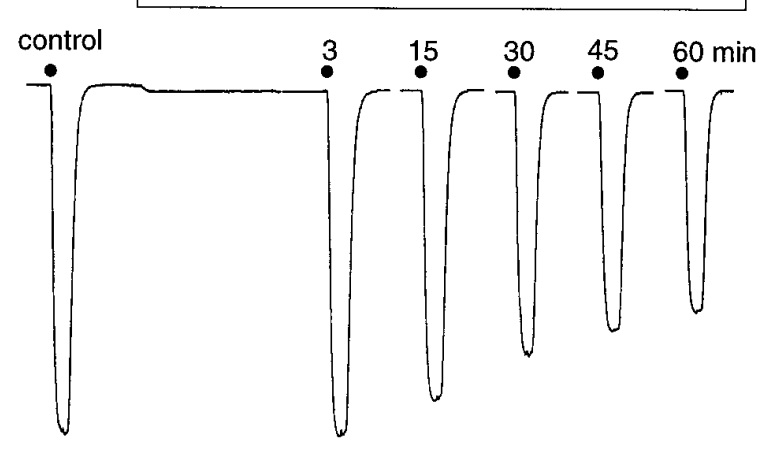

$10 \mu \mathrm{M}$ nicotine

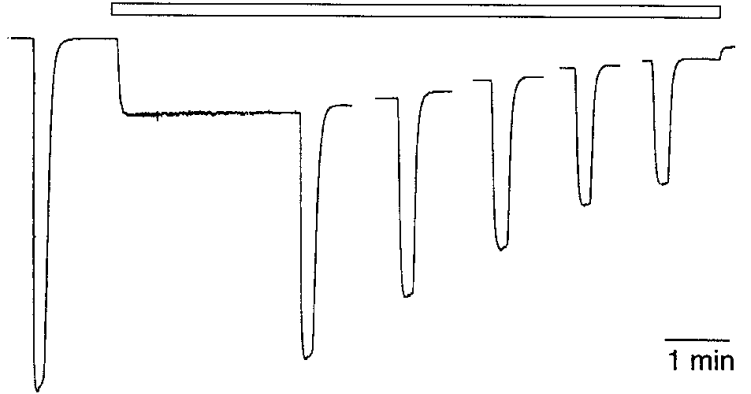

Figure 4. The time course and extent of desensitization are concentration-dependent. $A$, Plot of the peak amplitudes of the currents induced by $\mathrm{ACh}$ test pulses $(100 \mu \mathrm{M})$ with respect to time before and during continuous perfusion with $1 \mu \mathrm{M}$ (open squares), $10 \mu \mathrm{M}$ (filled circles), or $30 \mu \mathrm{M}$ (open circles) nicotine in oocytes expressing $\alpha 3 \beta 4$ receptors. $\tau_{\mathrm{d}}$ is the time constant for a single exponential fit to the time course of desensitization. The arrowheads represent near-equilibrium conditions at which the magnitude of desensitization was estimated (see Fig. 5). B, Representative traces of currents induced by ACh test pulses before (control) and at the indicated times during incubation with either $1 \mu \mathrm{M}$ (top traces) or $10 \mu \mathrm{M}$ (bottom traces) nicotine. All data were obtained in calcium-free media.

desensitization among subtypes were compared by fitting single exponentials to the recovery phase of the response after washout of $1 \mu \mathrm{M}$ nicotine. Receptors containing $\alpha 4$ subunits (i.e., nAChRs with a higher-affinity desensitized state) recovered more slowly from desensitization than those containing $\alpha 3$ subunits $(t=21.2$; $p<0.01)$. This result is not unexpected, because recovery ultimately involves an unbinding of agonist and a change in the receptor from desensitized to activatable; this is likely to be the slowest for the highest affinity receptor. Indeed, for $\alpha 4 \beta 4$ receptors, recovery often was incomplete even with $2 \mathrm{hr}$ washout (Fig. $6 B)$. On the other hand, $\alpha 3 \beta 2$ receptors recovered within a few minutes (Fig. $6 C$ ). Additionally, receptors containing $\beta 4$ subunits (i.e., nAChRs in which the time course of desensitization development is slower) recovered more slowly than those containing $\beta 2$ subunits $(t=8.4 ; p<0.05$; Fig. $6 A)$. Thus, $\alpha 3 \beta 4$ receptors show a rate of recovery intermediate of $\alpha 3 \beta 2$ receptors and $\alpha 4 \beta 4$ receptors.

The above analysis assumed a single exponential recovery from desensitization. This is a reasonable assumption for $\beta 4$ containing receptors; however, it may be inaccurate for $\beta 2$ containing receptors. Receptors containing $\beta 2$ subunits require the sum of two components to describe the desensitization phase during a brief pulse (see Fig. 2). These data imply multiple desensitized states for these receptors (Feltz and Trautman, 1982; Boyd, 1987). Thus, it follows that recovery from desensitization also may have two components (Feltz and Trautman, 1982; Cachelin and Colquhoun, 1989; Lester and Dani, 1995).

Recovery from desensitization for muscle-type nAChRs has been shown to be influenced by calcium-dependent mechanisms (Hardwick and Parsons, 1996). Thus, it is possible that similar mechanisms control the recovery of neuronal nAChRs. Because of the long duration of recordings necessary to examine the slow recovery from desensitization at low concentrations of nicotine, we used, instead, a paired-pulse approach to test the influence of calcium on the recovery from desensitization. A single $3 \mathrm{~min}$ application of nicotine at near $\mathrm{EC}_{50}$ concentrations was followed at a known interval by a second test pulse of nicotine, and the fractional recovery from desensitization was estimated in both calcium-free and calcium-containing media (Fig. 7). To reduce variability, often we tested the same oocyte under both conditions. Our results indicate that calcium has little effect on recovery from desensitization of nAChRs, although for some subtypes, e.g., $\alpha 4 \beta 2$, the rate of recovery may be enhanced in the presence of calcium $(t=31.1 ; p<0.01)$.

The outcome of prolonged exposure to nicotine is determined initially by the balance between receptor activation and desensitization at a particular nicotine concentration. To illustrate how this balance varies for different $\mathrm{nAChR}$ subtypes, we have replotted the activation and desensitization curves (Figs. $1 A, 5$ ) on the same axes (Fig. 8). The concentration range in which the activation and desensitization curves overlap indicates a "window current" (Steinbach, 1990), a region over which nicotine always produces some nAChR channel activation, because desensitization will be incomplete. At tobacco-related concentrations (60$300 \mathrm{~nm}$; Benowitz et al., 1989) the main effect of nicotine will be to desensitize nAChRs (see Table 1), thus reducing the population of receptors available for potential stimulation by endogenously released ACh (see Lester and Dani, 1995). However, for the higher affinity $\alpha 4$ subunit-containing nAChRs, nicotine at these concentrations will produce some channel activation.

\section{$\alpha 7$ receptor desensitization and activation by nicotine}

Although the above data demonstrate that $\alpha$ and $\beta$ subunits differentially influence the desensitization process, not all expressed $\mathrm{nAChRs}$ require $\beta$ subunits for channel formation or, indeed, for desensitization (e.g., $\alpha 7$ receptors; Couturier et al., 1990). For these receptors, desensitization characteristics must be determined solely by the $\alpha$ subunit (see Revah et al., 1991). The demonstration that $\alpha 7$-containing receptors mediate a presynaptic release of transmitter in the continuous presence of low 


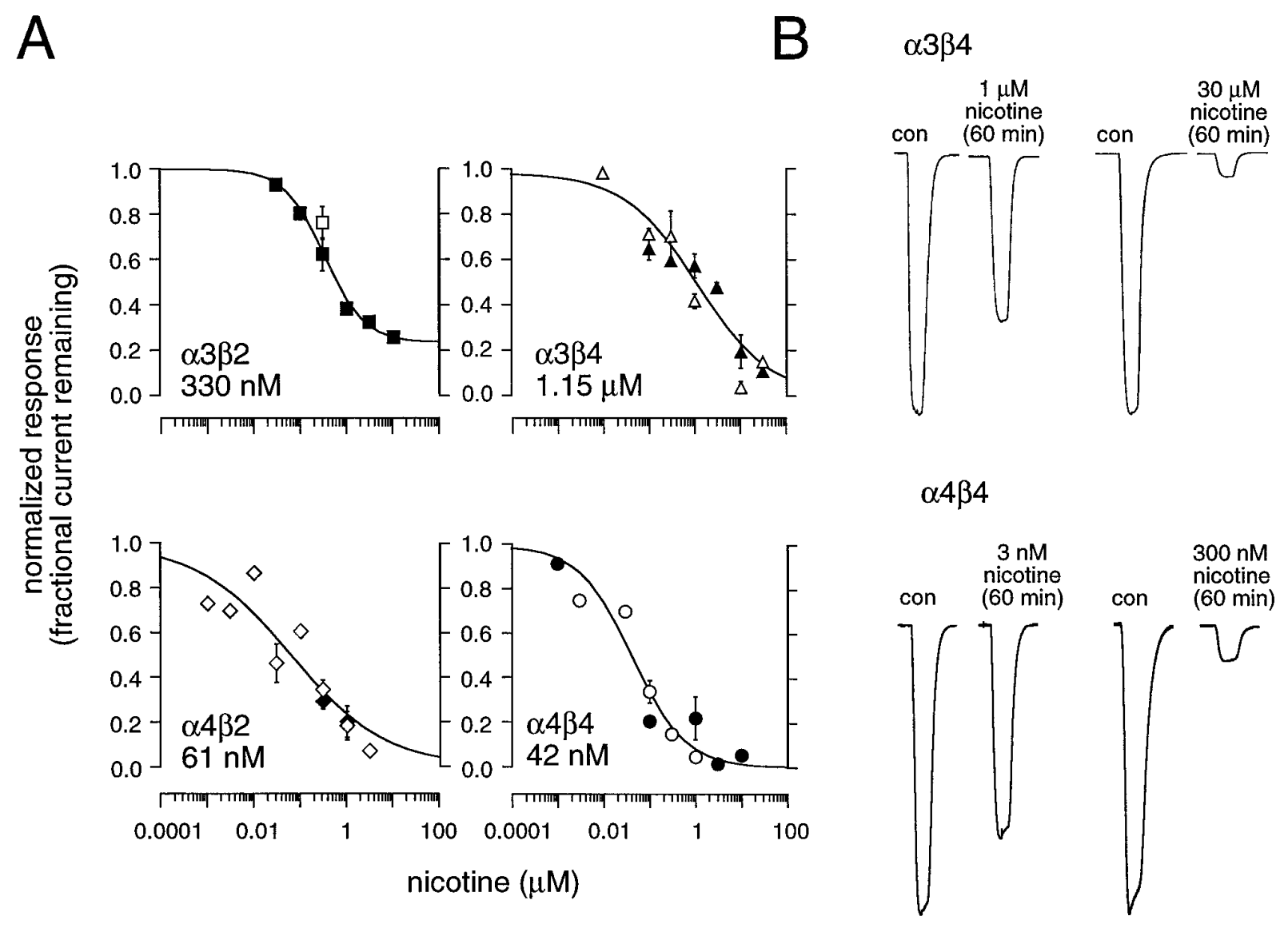

Figure 5. $\alpha 4$-containing $\mathrm{nAChRs}$ are desensitized by nanomolar concentrations of nicotine. $A$, Concentration-response plots of the ACh-induced fractional current remaining after chronic nicotine incubation in oocytes expressing $\alpha 3 \beta 2, \alpha 3 \beta 4, \alpha 4 \beta 2$, or $\alpha 4 \beta 4$ receptors. Some of the data were obtained by extrapolating the exponential fit to $60 \mathrm{~min}(\alpha 3 \beta 4$ and $\alpha 4 \beta 4)$ or $15-20 \mathrm{~min}(\alpha 3 \beta 2$ and $\alpha 4 \beta 2)$. The open and filled symbols represent data obtained in calcium-containing and calcium-free media, respectively. Each concentration data point represents between 1 and 10 measurements from separate oocytes. Solid lines are logistic fits to the mean of all the data obtained in calcium-free and calcium-containing media. Fits were constrained so that the maximal block could not exceed $100 \%$ and so that at infinitely low nicotine concentrations the block was zero. The half-maximal concentration for inhibition $\left(\mathrm{IC}_{50}\right)$ by nicotine is shown for each nAChR subtype. $B$, Examples of the inhibition of the ACh test pulses by different concentrations of nicotine for two receptor subtypes, $\alpha 3 \beta 4$ (top traces) and $\alpha 4 \beta 4$ (bottom traces). Each pair of traces shows the current induced before nicotine incubation (con) and the current remaining after a 60 min incubation, with the concentration of nicotine indicated.

concentrations of nicotine (McGehee et al., 1995; Gray et al., 1996) demands a detailed investigation of this subtype with respect to desensitization.

Figure 9 characterizes activation and desensitization for $\alpha 7$ receptors. As described by others (Couturier et al., 1990; Revah et al., 1991; Seguela et al., 1993), $\alpha 7$ nAChRs activate and desensitize rapidly to brief applications of high agonist concentrations (Fig. 9A). The dose-response relationship for nicotine reveals a relatively high $\mathrm{EC}_{50}(234 \mu \mathrm{M}$, calcium-free solutions), implying that $\alpha 7$ receptors have a very low apparent affinity for nicotine. There was an approximately twofold shift in the $\mathrm{EC}_{50}$ to lower values in the presence of extracellular calcium ions $(t=9.4$ $p<0.05$ ) with little effect on maximal activation (Fig. 9B). Our $\mathrm{EC}_{50}$ values of $79 \mu \mathrm{M}(3.6 \mathrm{mM}$ calcium) and $90 \mu \mathrm{M}(1.8 \mathrm{~mm}$ calcium) are slightly higher than those reported previously for human $\alpha 7$ (49 $\mu \mathrm{M}$; Gopalakrishnan et al., 1995), rat $\alpha 7(\sim 30 \mu \mathrm{M}$; Seguela et al., 1993), and chick $\alpha 7$ (24 $\mu \mathrm{M}$; Amar et al., 1993). Accounting for the decrease in single-channel conductance because of calcium (Mulle et al., 1992b; Amador and Dani, 1995), these data imply that calcium may increase both the affinity and efficacy of $\alpha 7 \mathrm{nAChRs}$ (Galzi et al., 1996). Desensitization of $\alpha 7$ receptors (and subsequent recovery from desensitization) at low concentrations of nicotine was rapid (Fig. 9C,D). However, in the absence of added calcium, desensitization was observed only for concentrations of nicotine above $\sim 1 \mu \mathrm{M}$, setting it apart from the various $\alpha \beta$-paired nAChRs. In calcium-free media, the halfmaximal concentration of nicotine for desensitization was $6 \mu \mathrm{M}$, the highest of all receptors tested (Fig. $9 F$ ). The addition of calcium significantly increased the effectiveness of nicotine to desensitize $\alpha 7$-expressing receptors $\left(\mathrm{IC}_{50}=1 \mu \mathrm{M} ; t=18.5 ; p<\right.$ $0.01)$, with little observable effect on the time course of desensitization $(t=2.7 ; p>0.05$; Fig. $9 E, F)$. Thus, although $\alpha 7$ receptors exhibit pronounced and rapid desensitization, much higher concentrations of nicotine are required.

\section{DISCUSSION}

Examination of a number of expressed nAChRs reveals patterns of functional contributions of particular $\alpha$ and $\beta$ subunits to the process of activation and desensitization. For heteromeric nAChRs we find that the $\alpha$ subunit makes a significant contribution in determining the apparent nicotine affinity of the active and 

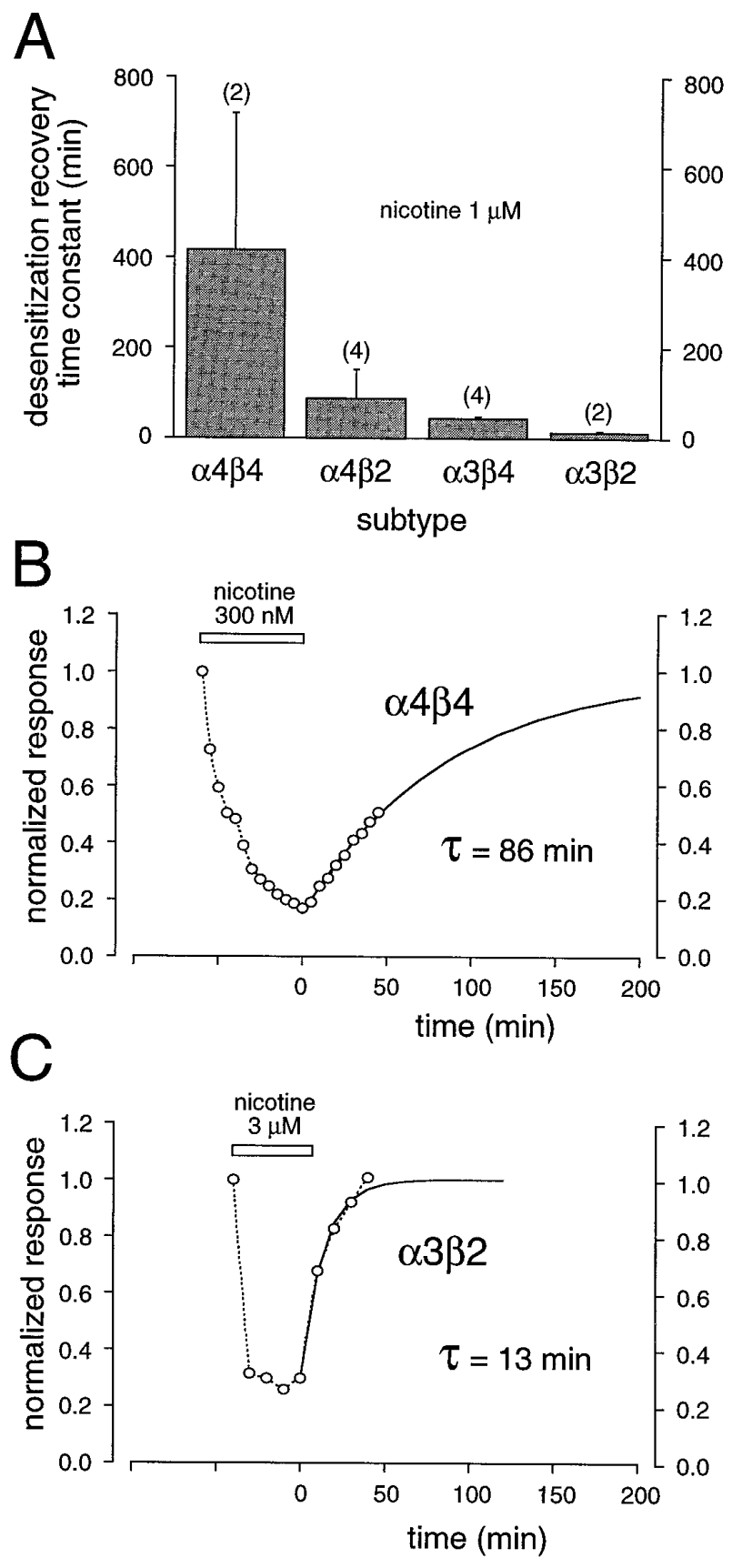

Figure 6. Time course of recovery from nicotine-induced desensitization is subunit-dependent. $A$, Histogram of the mean time constants for a single exponential fit to the time course of recovery from desensitization induced by $1 \mu \mathrm{M}$ nicotine for a number of nAChR subtypes. Data from experiments in calcium-free and calcium-containing media were combined. The number of experiments for each subtype is indicated in parentheses. Recovery was estimated after nicotine incubation of 15-20 $\min (\alpha 3 \beta 2$ and $\alpha 4 \beta 2$ receptors) and $60 \min (\alpha 3 \beta 4$ and $\alpha 4 \beta 4$ receptors). $B$, Plot of normalized peak current amplitudes $(\mathrm{o}-\mathrm{O})$ induced by a repetitively applied ACh test pulse ( $5 \mu \mathrm{M} ; 5$ min intervals) with respect to time before, during (open bar), and after continuous perfusion with $300 \mathrm{~nm}$ nicotine in calcium-containing media for an oocyte expressing $\alpha 4 \beta 4$ receptors. $C$, Plot of normalized peak amplitudes of currents $(\mathrm{o}-\mathrm{o})$ induced by a repetitively applied ACh test pulse $(100 \mu \mathrm{M} ; 10 \mathrm{~min}$ intervals) with respect to time before, during (open bar), and after continuous perfusion with $3 \mu \mathrm{M}$ nicotine in calcium-free media for an oocyte expressing $\alpha 3 \beta 2$ receptors. The time constants $(\tau)$ in $B$ and $C$ result from single exponential fits (solid line) to the time course of recovery from desensitization. The exponential fit assumed recovery to control values. desensitized states of an nAChR; the $\beta$ subunit makes a significant contribution in determining the overall time course of the desensitization development of an nAChR. In addition, we have demonstrated that external calcium ions, while producing subtle effects on the kinetics and apparent affinities of nicotine for activation and desensitization of the $\alpha \beta \mathrm{nAChRs}$, do not alter the pattern of contributions of these various subunits. In contrast, for the homomeric $\alpha 7 \mathrm{nAChR}$, which displays faster kinetics and generally lower affinities for nicotine than the $\alpha \beta$ pairs, we find that calcium increases the apparent affinity of nicotine for both the active and desensitized states.

\section{Contribution of the $\alpha$ subunit to activation of $\mathrm{nAChRs}$ by nicotine}

Activation of various nAChR subtypes by nicotine produced straightforward results: $\alpha 4$-containing receptors have higher apparent affinities for nicotine than $\alpha 3$-containing receptors. Vibat et al. (1995) have observed a similar leftward shift in nicotineinduced dose-response curves on switching an $\alpha 4$ subunit for an $\alpha 3$ subunit in receptors containing rat $\beta 4$ subunits. Chick and human $\alpha 4 \beta 2$ receptors (Bertrand et al., 1990; Peng et al., 1994; Buisson et al., 1996) also are activated more potently by nicotine than are $\alpha 3 \beta 4$ receptors (Hussy et al., 1994). If the $\alpha$ subunit is the principal agonist-binding subunit, these results could indicate differences in agonist-binding affinity between these two $\alpha$ subunits. However, this is likely an oversimplification. First, $\beta$ subunits, as noted above, also affect the apparent affinity for some nAChR subtypes (Cachelin and Jaggi, 1991; Gross et al., 1991; Luetje and Patrick, 1991; Cohen et al., 1995), and, second, apparent affinity reflects both agonist binding and channel gating, so the observed subtype differences in concentration-response curves could represent differences in either affinity and/or efficacy. By examining the contribution of $\beta$ subunits to the concentration-response relationship, Cohen et al. (1995) have argued that affinity differences cannot be explained by a change in efficacy and that, by analogy with muscle nAChRs, the binding site is likely to form between both $\alpha$ and $\beta$ subunits. This argument is supported by observations that antagonist sensitivity also is determined by both $\alpha$ and $\beta$ subunits (Cachelin and Rust, 1995; Harvey and Luetje, 1996). It is possible, therefore, that our activation results are attributable to the fortuitous selection of particular nAChRs.

\section{$\alpha$ and $\beta$ subunits contribute to nicotine-induced desensitization}

The desensitization time course for nAChR subtypes, measured either directly from the current decay during brief nicotine applications or from the decrease in response to ACh test pulses in the presence low concentrations of nicotine, is influenced for the most part by the $\beta$ subunit: fast for $\beta 2$-containing $\mathrm{nAChRs}$ and slow for $\beta 4$-containing $\mathrm{nAChRs}$. These data extend previous findings for rat nAChRs (Cachelin and Jaggi, 1991; Hsu et al., 1995). Because homomeric $\alpha 7$ receptors also desensitize, it is likely that the $\beta$ subunit plays a modulatory, rather than a permissive role, in desensitization.

Studies investigating ACh desensitization of both chick and rat nAChRs, in which the $\beta$ subunit was not varied, imply that the $\alpha$ subunit also can influence the time course of desensitization (Gross et al., 1991; Vibat et al., 1995). Aside from agonistdependent differences in desensitization, the contribution of $\alpha$ subunits may be explained if one considers how desensitization was measured. For example, although short applications of nico- 


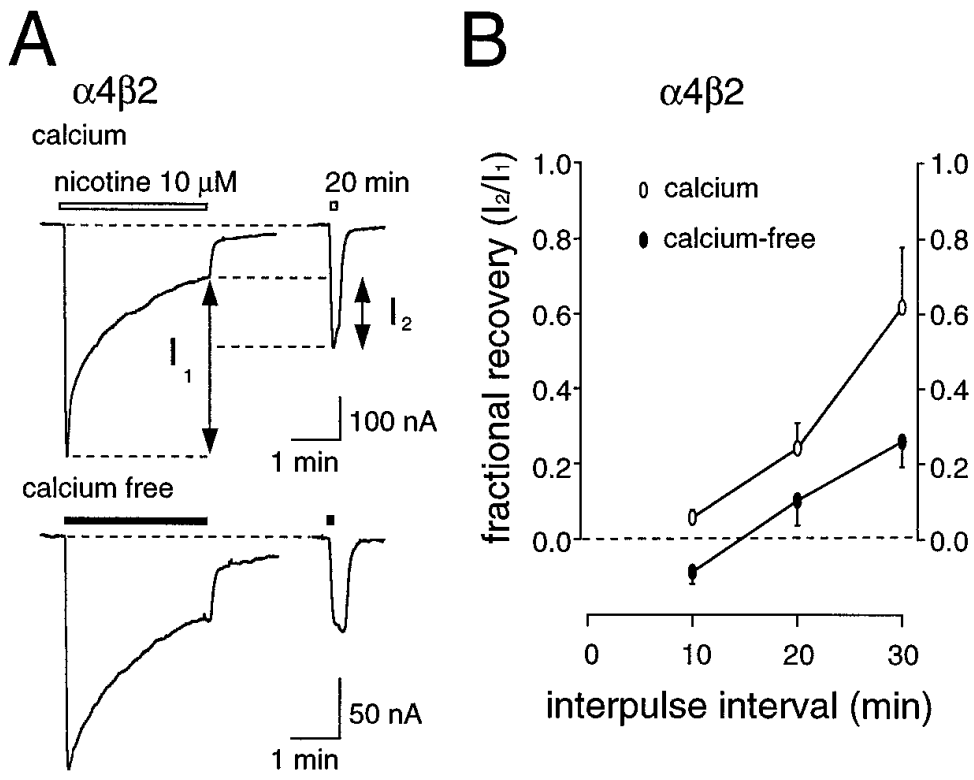

\section{C}

$\alpha 4 \beta 2$

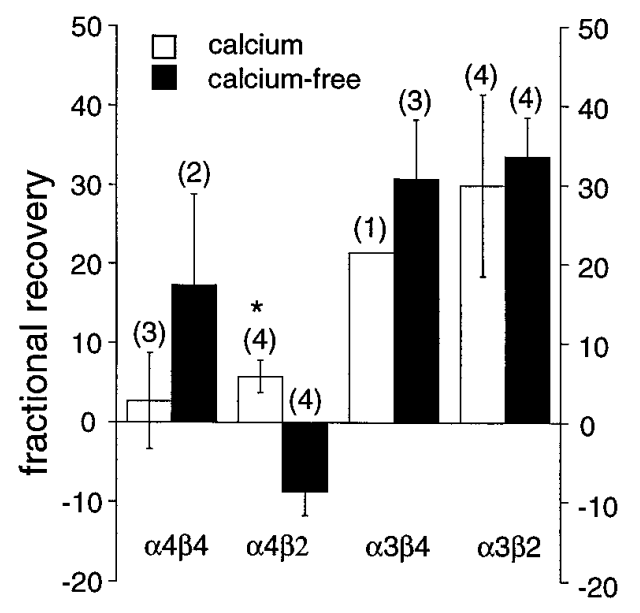

Figure 7. Subunit-specific differences in the recovery from desensitization. $A$, Paired-pulses of nicotine $(10 \mu \mathrm{M})$ applied to an oocyte expressing $\alpha 4 \beta 2$ receptors at an interpulse interval of $20 \mathrm{~min}$. To account for differences in the relative amount of desensitization in calcium-containing and calcium-free media, we quantified recovery by measuring the fractional increase in the amplitude of the second pulse $\left(I_{2}\right)$ with respect to the amount of desensitization $\left(I_{1}\right)$ induced by a $3 \mathrm{~min}$ application of nicotine. $B$, Plot of the fractional recovery from desensitization at various interpulse intervals in the presence (open circles) or absence ( filled circles) of added calcium. $C$, Histogram of the relative recovery from desensitization for each $\mathrm{nAChR}$ subtype in the presence or absence of calcium. The number of experiments for each subtype is indicated in parentheses. The interpulse intervals were 10 min for both $\alpha 4 \beta 4$ receptors and $\alpha 4 \beta 2$ receptors, $5 \mathrm{~min}$ for $\alpha 3 \beta 4$ receptors, and $3 \mathrm{~min}$ for $\alpha 3 \beta 2$ receptors. Individual oocytes expressing $\alpha 4 \beta 2$ and $\alpha 3 \beta 2$ receptors were measured in both calcium-free and calcium-containing media. Significant differences $(p<0.05)$ between the results obtained in the two conditions are indicated by the asterisk.

tine demonstrate that $\alpha 3 \beta 2$ receptors desensitize faster than $\alpha 4 \beta 2$ receptors (Gross et al., 1991; Vibat et al., 1995), the reverse is true when the desensitization time course is followed by repetitive pulses (Vibat et al., 1995). Such differences may be explained if one considers a cyclical model for desensitization (Katz and Thesleff, 1957). In the continued presence of agonist, the time course of desensitization reflects the rates governing equilibration between the active/open and the desensitized states. These rates
Figure 8. Receptor activation and desensitization have subtype-specific overlapping concentration ranges. Shown are summary concentration-response plots for activation in calcium-containing media (filled symbols; solid lines) and for desensitization (open symbols) of four nAChR subtypes. For comparison, the logistic fits to the activation concentration-response curves obtained in calcium-free media are indicated with dashed lines.

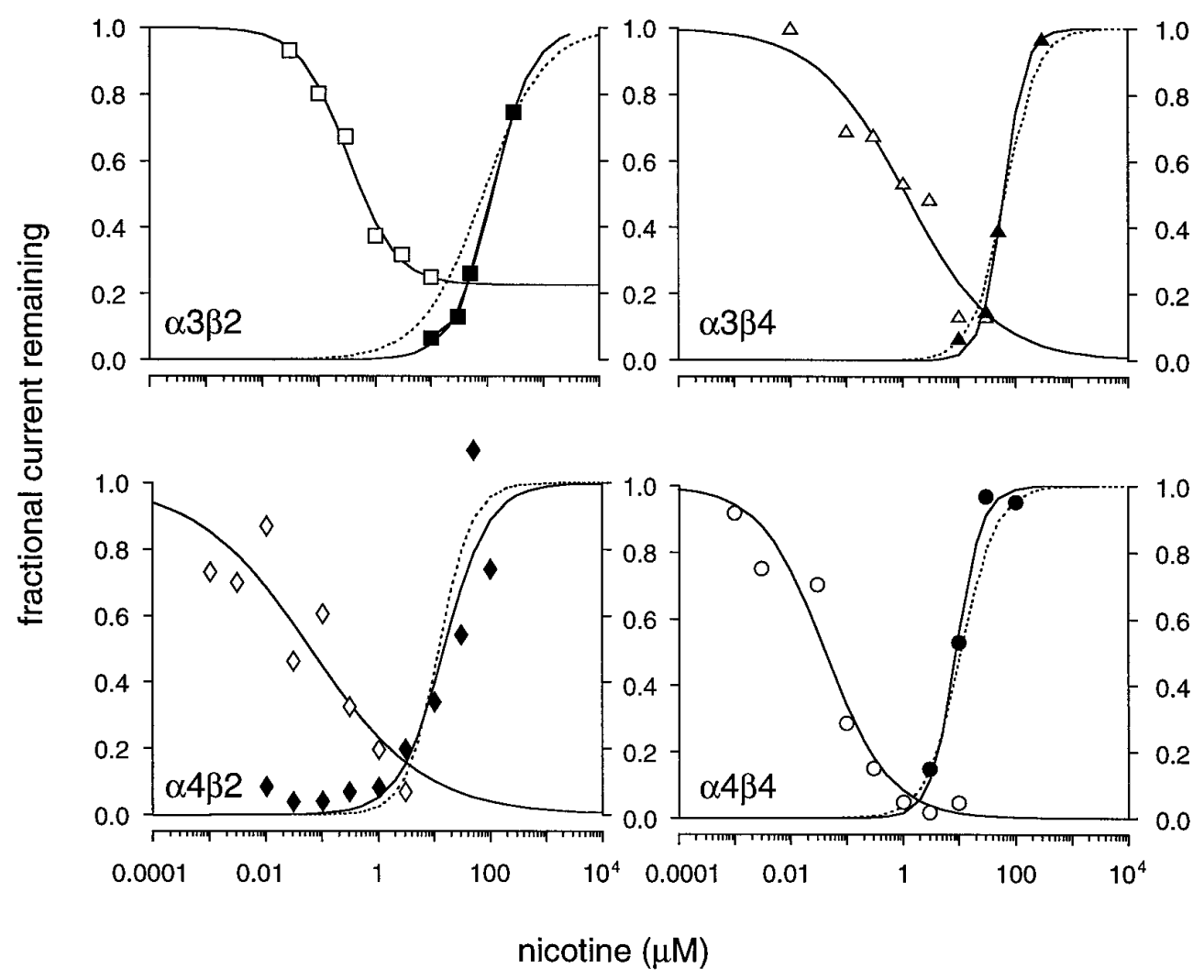


A

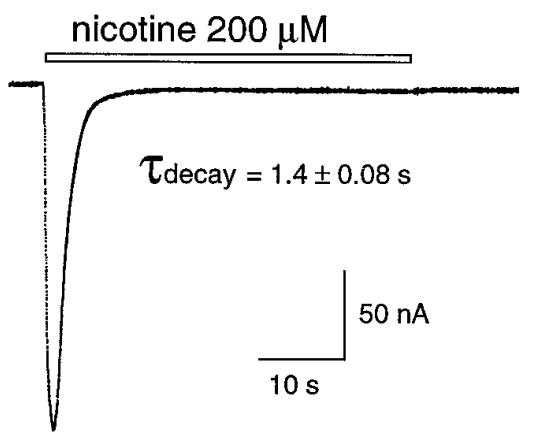

C

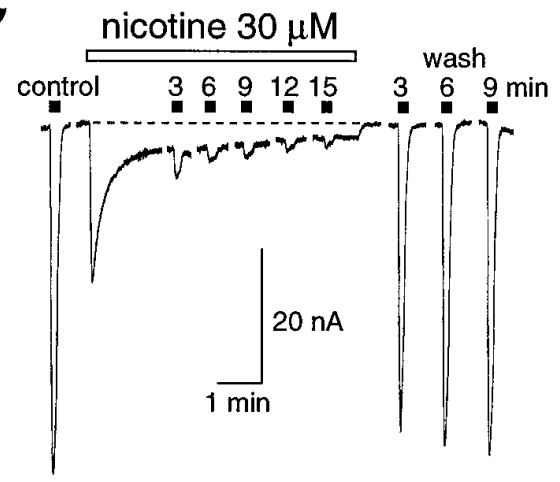

$E$

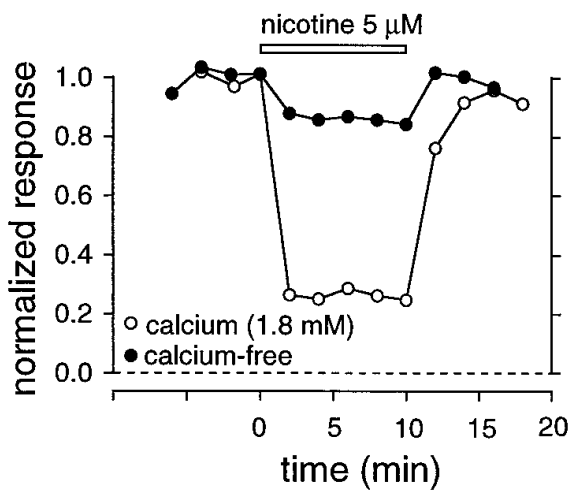

B

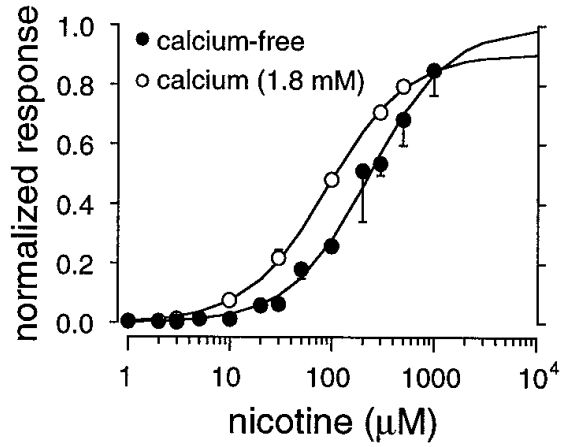

D

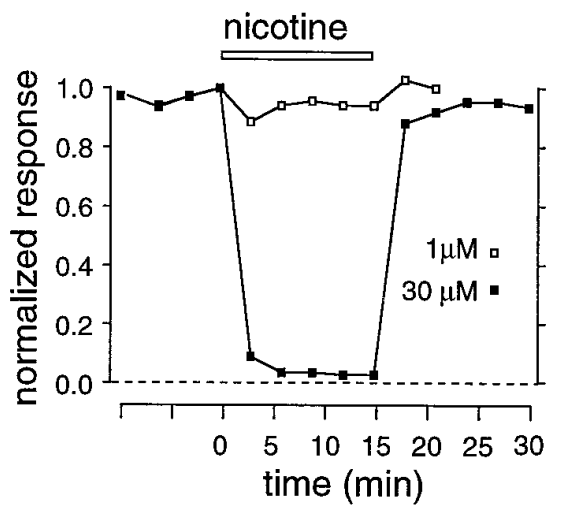

F

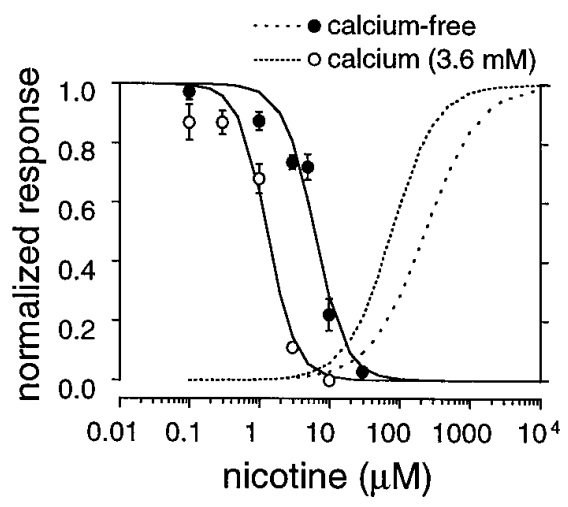

Figure 9. Homomeric $\alpha 7$ receptors have low affinity for nicotine and rapid desensitization kinetics. $A$, Example of rapid desensitization induced by $200 \mu \mathrm{M}$ nicotine in calcium-free media in an oocyte expressing $\alpha 7$ receptors. The mean time constant $\left(\tau_{\text {decay }}\right)$ resulting from a single exponential fit to the decay phase is indicated; the steady-state/peak current ratio was $0.023 \pm 0.003$ (10 observations from four cells). $B$, Concentration-response curves for nicotineinduced activation. The solid lines are logistic fits to the data sets. The $\mathrm{EC}_{50}$ values were $90 \mu \mathrm{M}(n=4)$ and $234 \mu \mathrm{M}$ $(n=10)$ in the presence (open circles) or absence (closed circles) of calcium, respectively. The Hill coefficients for each were 1.1. $C$, Example of the currents induced by test pulses of ACh $(100 \mu \mathrm{M})$ before (control), during continuous exposure, and after washout of $30 \mu \mathrm{M}$ nicotine in calcium-free media. $D$, Plot of the peak test pulse amplitude (ACh, 100 $\mu \mathrm{M})$ in two different oocytes expressing $\alpha 7$ receptors before, during, and after incubation with $1 \mu \mathrm{M}$ (open symbols) or $30 \mu \mathrm{M}$ (closed symbols) nicotine in calcium-free media. $E$, Plot of the peak test pulse amplitude induced by $\mathrm{ACh}$ before, during, and after incubation of an $\alpha 7$-expressing oocyte with a $10 \mathrm{~min}$ application of $5 \mu \mathrm{M}$ nicotine in the presence (open circles) or absence (closed circles) of calcium. $F$, Concentration-response curve for nicotine-induced inhibition of the $\mathrm{ACh}$ test pulse in $\alpha 7$ receptor-expressing oocytes. The solid lines are logistic fits, and the halfmaximal concentrations for inhibition $\left(\mathrm{IC}_{50}\right)$ by nicotine were 1.3 and $6.2 \mu \mathrm{M}$ in the presence (open circles) or absence (closed circles) of calcium, respectively. The activation concentration-response curves obtained in the same conditions are shown (dashed lines) for comparison. would be expected to be faster for $\alpha 3 \beta 2$ receptors than $\alpha 4 \beta 2$ receptors; hence $\alpha 3 \beta 2$ receptors would desensitize faster in the continued presence of agonist. However, on removal of agonist, recovery can occur by the unbinding of agonist from the desensitized state (Dilger and Lui, 1993). Thus, if recovery in the absence of agonist is slow for $\alpha 4 \beta 2$ receptors as compared with $\alpha 3 \beta 2$ receptors, as we have observed, then desensitization measured by repetitive pulses (the agonist is absent in the interpulse interval) over a longer period of time would show a greater accumulation of $\alpha 4 \beta 2$ receptors in the desensitized state (Vibat et al., 1995).

\section{Relationship between nAChR channel properties and receptor regulation}

Prolonged nicotine exposure leads to subtype-specific modulation (Schwartz and Kellar, 1985; Stolerman and Shoaib, 1991; Marks et al., 1993; Hsu et al., 1995; Dani and Heinemann, 1996). Because these changes arise at low nicotine concentrations, one must consider individual differences in $\mathrm{nAChR}$ behavior at these concentrations. A complete understanding of the cellular effects resulting from prolonged exposure to nicotine requires knowledge of the balance between activated and desensitized states of receptor subtypes (Steinbach, 1990; Balfour, 1994). All nAChRs studied desensitize at lower concentrations than they activate (Katz and Thesleff, 1957); however, for each receptor there is a concentration range over which desensitization is incomplete and activation has begun. Particularly for $\alpha 4 \beta 2$ receptors, this window approximately corresponds to the estimated levels of nicotine found in the brain after tobacco smoke inhalation (Benowitz et al., 1989). 
For certain nAChR subtypes, e.g., $\alpha 4 \beta 2$ receptors, chronic nicotine exposure results in pronounced upregulation of receptor number (Flores et al., 1992; Peng et al., 1994; Gopalakrishnan et al., 1996). Because the desensitized state of $\alpha 4 \beta 2$ receptors has high nicotine affinity (it is desensitized for the most part by $1 \mu \mathrm{M}$ nicotine), this state may be the trigger for the increase in receptor number (Ochoa et al., 1990; Peng et al., 1994; Gopalakrishnan et al., 1996). This idea is supported by evidence that exposure to $\mathrm{nAChR}$ antagonists also induces an increase in receptor number; i.e., a nonactive state of the receptor is a sufficient stimulus (Collins et al., 1994; Peng et al., 1994; Gopalakrishnan et al., 1996). An accompanying increase in receptor sensitivity then could be a direct consequence of increased receptor number (Rowell and Wonnacott, 1990; Gopalakrishnan et al., 1996). However, others have observed a downregulation in receptor function (Marks et al., 1993; Collins et al., 1994; Peng et al., 1994). The relatively high activation affinity of $\alpha 4 \beta 2$ receptors means that, although most receptors are desensitized by tobaccorelated levels of nicotine, a continuous low level of activity remains. Prolonged low rates of synaptic activity have been associated with an NMDA-mediated calcium-dependent long-term depression of glutamatergic responses (Dudek and Bear, 1992; Mulkey and Malenka, 1992). An intriguing possibility is that functional downregulation of $\mathrm{nAChRs}$ is related to their high calcium permeability. The concept of an overlapping agonist concentration window for activation and desensitization could account for the dual up- and downregulation of $\alpha 4 \beta 2$ receptor function (Peng et al., 1994; Gopalakrishnan et al., 1996); the precise agonist concentration would control the relative balance between active and desensitized receptor states.

Differences in regulation among nAChRs could be explained by subtype-specific nicotine sensitivities of both the desensitized and active receptor states. Studies on the homomeric $\alpha 7$ receptor provide some support for this notion. The finding that nanomolar concentrations of nicotine can, via $\alpha 7$-like presynaptic nAChRs, cause a continuous release of glutamate from synaptic terminals (McGehee et al., 1995; Gray et al., 1996) is consistent with the present observation that these concentrations of nicotine would cause little desensitization of $\alpha 7$ receptors. The desensitization hypothesis for increases in $\mathrm{nAChR}$ number would predict that $\alpha 7$ receptors should not be upregulated as readily as $\alpha 4 \beta 2$ receptors. In fact, the number of $\alpha$-bungarotoxin ( $\alpha$-BTX) binding sites, putatively formed from $\alpha 7$ subunits (Couturier et al., 1990), can be upregulated by chronic nicotine treatment. However, relatively high concentrations of nicotine are required (Marks et al., 1983). At lower concentrations of nicotine (that result in increased $\alpha 4 \beta 2$ receptor number), $\alpha 7 / \alpha$-BTX receptors are unaffected (Marks et al., 1985; Collins et al., 1994).

It should be noted that some CNS nAChRs, including $\alpha 7$, may contain more than a single type of $\alpha$ or $\beta$ subunit (Conroy et al., 1992; Anand et al., 1993; Ramirez-Latorre et al., 1996; Wang et al., 1996). Also, there may be some differences between nAChRs expressed in oocytes and mammalian cells (Peng et al., 1994; Wong et al., 1995; Buisson et al., 1996). Such differences may result in shifts in concentration-response curves and/or desensitization properties (Ramirez-Latorre et al., 1996; Wang et al., 1996). Regardless, knowledge of the subunit contribution to activation and desensitization is important for accurate predictions of the differential effects of tobacco-related levels of nicotine on CNS nAChRs.

\section{REFERENCES}

Amador M, Dani JA (1995) Mechanism for modulation of nicotinic acetylcholine receptors that can influence synaptic transmission. J Neurosci 15:4525-4532.

Amar M, Thomas P, Johnson C, Lunt GG, Wonnacott S (1993) Agonist pharmacology of the neuronal alpha 7 nicotinic receptor expressed in Xenopus oocytes. FEBS Lett 327:284-288.

Anand R, Conroy WG, Schoepfer R, Whiting P, Lindstrom J (1991) Neuronal nicotinic acetylcholine receptors expressed in Xenopus oocytes have a pentameric quaternary structure. J Biol Chem 266:11192-11198.

Anand R, Peng X, Lindstrom J (1993) Homomeric and native alpha 7 acetylcholine receptors exhibit remarkably similar but non-identical pharmacological properties, suggesting that the native receptor is a heteromeric protein complex. FEBS Lett 327:241-246.

Balfour DJK (1994) Neural mechanisms underlying nicotine dependence. Addiction 89:1419-1423.

Benowitz NL, Porchet H, Jacob III P (1989) Nicotinic dependence and tolerance in man: pharmacokinetic and pharmacodynamic investigations. Prog Brain Res 79:279-287.

Bertrand D, Ballivet M, Rungger D (1990) Activation and blocking of neuronal nicotinic acetylcholine receptor reconstituted in Xenopus oocytes. Proc Natl Acad Sci USA 87:1993-1997.

Boyd ND (1987) Two distinct kinetic phases of desensitization of acetylcholine receptors of clonal rat PC12 cells. J Physiol (Lond) 389:45-67.

Buisson B, Gopalakrishnan M, Arneric SP, Sullivan JP, Bertrand D (1996) Human $\alpha 4 \beta 2$ neuronal nicotinic acetylcholine receptor in HEK 293 cells: a patch-clamp study. J Neurosci 16:7880-7891.

Cachelin AB, Colquhoun D (1989) Desensitization of the acetylcholine receptor of frog end-plates measured in a Vaseline-gap voltage clamp. J Physiol (Lond) 415:159-188.

Cachelin AB, Jaggi R (1991) $\beta$ subunits determine the time course of desensitization in rat $\alpha 3$ neuronal nicotinic acetylcholine receptors. Pflügers Arch 419:579-582.

Cachelin AB, Rust G (1995) $\beta$ subunits codetermine the sensitivity of rat neuronal nicotinic receptors to antagonists. Pflügers Arch 429:449-451.

Clark PBS (1993) Nicotinic receptors in mammalian brain: localization and relation to cholinergic innervation. Prog Brain Res 98:77-83.

Cohen BN, Figl A, Quick MW, Labarca C, Davidson N, Lester HA (1995) Regions of $\beta 2$ and $\beta 4$ responsible for differences between the steady-state dose-response relationships of the $\alpha 3 \beta 2$ and $\alpha 3 \beta 4$ neuronal nicotinic receptors. J Gen Physiol 105:745-764.

Collins AC, Luo Y, Selvaag S, Marks MJ (1994) Sensitivity to nicotine and brain nicotinic receptors are altered by chronic nicotine and mecamylamine infusion. J Pharmacol Exp Ther 271:125-133.

Conroy WG, Vernallis AB, Berg DK (1992) The $\alpha 5$ gene product assembles with multiple acetylcholine receptor subunits to form distinctive receptor subtypes in brain. Neuron 9:679-691.

Cooper C, Courturier S, Ballivet M (1991) Pentameric structure and subunit stoichiometry of a neuronal nicotinic acetylcholine receptor. Nature 350:235-238.

Couturier S, Bertrand D, Matter JM, Hernandez MC, Bertrand S, Millar N, Valera S, Barkas T, Ballivet M (1990) A neuronal nicotinic acetylcholine receptor subunit (alpha 7) is developmentally regulated and forms a homo-oligomeric channel blocked by alpha-BTX. Neuron 5:847-856.

Dani JA, Heinemann S (1996) Molecular and cellular aspects of nicotine abuse. Neuron 16:905-908.

Dilger JP, Lui Y (1993) Desensitization of acetylcholine receptors in BC3H-1 cells. Pflügers Arch 420:479-485.

Dineley-Miller K, Patrick J (1992) Gene transcripts for the nicotinic acetylcholine receptor subunit, beta 4 , are distributed in multiple areas of the rat central nervous system. Mol Brain Res 16:339-344.

Dudek SM, Bear MF (1992) Homosynaptic long-term depression in area CA1 of hippocampus and effects of $N$-methyl-D-aspartate receptor blockade. Proc Natl Acad Sci USA 89:4363-4367.

Duvoisin RM, Deneris ES, Patrick J, Heinemann S (1989) The functional diversity of the neuronal nicotinic acetylcholine receptor is increased by a novel subunit $\beta 4$. Neuron 3:487-496.

Feltz A, Trautmann A (1982) Desensitization at the frog neuromuscular junction: a biphasic process. J Physiol (Lond) 322:257-272.

Finney D (1971) Probit analysis, 3rd Ed. New York: Cambridge UP.

Flores CM, Rogers SW, Pabreza LA, Wolfe BB, Kellar KJ (1992) A subtype of nicotinic cholinergic receptor in rat brain is composed of $\alpha 4$ 
and $\beta 2$ subunits and is up-regulated by chronic nicotine treatment. J Pharmacol Exp Ther 41:31-37.

Galzi JL, Bertrand S, Corringer PJ, Changeux JP, Bertrand D (1996) Identification of calcium binding sites that regulate potentiation of a neuronal nicotinic acetylcholine receptor. EMBO J 15:5824-5832.

Gopalakrishnan M, Buisson B, Touma E, Giordano T, Campbell JE, Hu IC, Donnelly-Roberts D, Arneric SP, Bertrand D, Sullivan JP (1995) Stable expression and pharmacological properties of the human alpha 7 nicotinic acetylcholine receptor. Eur J Pharmacol 290:237-246.

Gopalakrishnan M, Monteggia LM, Anderson DJ, Molinari EJ, PiattoniKaplan M, Donnelly-Roberts D, Arneric SP, Sullivan JP (1996) Stable expression, pharmacologic properties, and regulation of the human neuronal nicotinic acetylcholine alpha 4 beta 2 receptor. J Pharmacol Exp Ther 276:289-297.

Gray R, Rajan A, Radcliffe KA, Yakehiro M, Dani JA (1996) Hippocampal synaptic transmission enhanced by low concentrations of nicotine. Nature 383:713-716.

Gross B, Ballivet M, Rungger D, Bertrand D (1991) Neuronal nicotinic acetylcholine receptors expressed in Xenopus oocytes: role of the alpha subunit in agonist sensitivity and desensitization. Pflügers Arch 419:545-551.

Hardwick JC, Parsons RL (1996) Activation of the protein phosphatase calcineurin during carbachol exposure decreases the extent of recovery from end-plate desensitization. J Neurophysiol 76:3609-3616.

Harvey SC, Luetje CW (1996) Determinants of competitive antagonist sensitivity on neuronal nicotinic receptor $\beta$ subunits. J Neurosci 16:3798-3806.

Hussy N, Ballivet M, Bertrand D (1994) Agonist and antagonist effects of nicotine on chick neuronal receptors are defined by $\alpha$ and $\beta$ subunits. J Neurophysiol 72:1317-1326.

Hsu Y-N, Amin J, Weiss DS, Wecker L (1995) Sustained nicotine exposure differentially affects $\alpha 3 \beta 2$ and $\alpha 4 \beta 2$ neuronal nicotinic receptors expressed in Xenopus oocytes. J Neurochem 66:667-675.

Katz B, Thesleff S (1957) A study of the desensitization produced by acetylcholine at the motor end-plate. J Physiol (Lond) 138:63-80.

Lester RAJ, Dani JA (1995) Acetylcholine receptor desensitization induced by nicotine in rat medial habenula neurons. J Neurophysiol 74:195-206.

Luetje CW, Patrick JP (1991) Both $\alpha$ and $\beta$ subunits contribute to the agonist sensitivity of neuronal nicotinic acetylcholine receptors. J Neurosci 11:837-845.

Maconochie DJ, Knight DE (1992) A study of the bovine adrenal chromaffin nicotinic receptor using patch-clamp and concentration-jump techniques. J Physiol (Lond) 454:129-153.

Marks MJ, Burch JB, Collins AC (1983) Effects of chronic nicotine infusion on tolerance development and nicotinic receptors. J Pharmacol Exp Ther 226:817-825.

Marks MJ, Stitzel JA, Collins AC (1985) Time course study of the effects of chronic nicotine infusion on drug response and brain receptors. J Pharmacol Exp Ther 235:619-628.

Marks MJ, Pauly JR, Gross SD, Deneris ES, Hermana-Borgmeyer I, Heinemann SF, Collins AC (1992) Nicotine binding and nicotinic receptor subunit RNA after chronic nicotine treatment. J Neurosci 12:2765-2784.

Marks MJ, Grady SR, Collins AC (1993) Downregulation of nicotinic receptor function after chronic nicotine infusion. J Pharmacol Exp Ther 266:1268-1276.

McGehee DS, Role LW (1995) Physiological diversity of nicotinic acetylcholine receptors expressed by vertebrate neurons. Annu Rev Physiol 57:521-546.

McGehee DS, Role LW (1996) Presynaptic ionotropic receptors. Curr Opin Neurobiol 6:342-349.

McGehee DS, Heath MJ, Gelber S, Devay P, Role LW (1995) Nicotine enhancement of fast excitatory synaptic transmission in CNS by presynaptic receptors. Science 269:1692-1696.

Morris BJ, Hicks AA, Wisden W, Darlison MG, Hunt SP, Barnard EA (1990) Distinct regional expression of nicotinic acetylcholine receptor genes in chick brain. Mol Brain Res 7:305-315.

Mulkey RM, Malenka RC (1992) Mechanisms underlying induction of homosynaptic long-term depression in area CA1 of the hippocampus. Neuron 9:967-975.

Mulle C, Choquet D, Korn H, Changeux JP (1992a) Calcium influx through nicotinic receptor in rat central neurons: its relevance to cellular regulation. Neuron 8:135-143.

Mulle C, Lena C, Changeux JP (1992b) Potentiation of nicotinic receptor response by external calcium in rat central neurons. Neuron 8:937-945.

Ochoa ELM, Li L, McNamee MG (1990) Desensitization of central cholinergic mechanisms and neuroadaptation to nicotine. Mol Neurobiol 4:251-287.

Peng X, Gerzanich V, Annad R, Whiting PJ, Lindstrom J (1994) Nicotine-induced increase in neuronal nicotinic receptors results from a decrease in the rate of receptor turnover. Mol Pharmacol 46:523-530.

Quick MW, Lester HA (1994) Methods for expression of excitability proteins in Xenopus oocytes. In: Methods in neurosciences (Conn PM, ed), pp 261-279. San Diego: Academic.

Ramirez-Latorre J, Yu CR, Qu X, Perin F, Karlin A, Role L (1996) Functional contributions of $\alpha 5$ subunit to neuronal acetylcholine receptor channels. Nature 380:347-351.

Rathouz MM, Berg DK (1994) Synaptic-type acetylcholine receptors raise intracellular calcium levels in neurons by two mechanisms. J Neurosci 14:6935-6945.

Revah F, Bertrand D, Galzi JL, Devillers-Thiery A, Mulle C, Hussy N, Bertrand S, Ballivet M, Changeux JP (1991) Mutations in the channel domain alter desensitization of a neuronal nicotinic receptor. Nature 353:846-849.

Role LW (1992) Diversity in primary structure and function of neuronal nicotinic acetylcholine receptor channels. Curr Opin Neurobiol 2:254-262.

Role LW, Berg DK (1996) Nicotinic receptors in the development and modulation of CNS synapses. Neuron 16:1077-1085.

Rowell PP, Wonnacott S (1990) Evidence for functional activity of upregulated nicotine binding sites in rat striatal synaptosomes. J Neurochem 55:2105-2110.

Schwartz RD, Kellar KJ (1985) In vivo regulation of $\left[{ }^{3} \mathrm{H}\right]$ acetylcholine recognition sites in brain by nicotinic cholinergic drugs. J Neurochem 45:427-433.

Seguela P, Wadiche J, Dineley-Miller K, Dani JA, Patrick JW (1993) Molecular cloning, functional properties, and distribution of rat brain alpha 7: a nicotinic cation channel highly permeable to calcium. J Neurosci 13:596-604.

Steinbach JH (1990) Mechanism of action of the nicotinic acetylcholine receptor. Ciba Found Symp 152:53-67.

Stolerman IP, Shoaib M (1991) The neurobiology of tobacco addiction. Trends Pharmacol Sci 12:467-473.

Vernino S, Amador M, Luetje CW, Patrick J, Dani JA (1992) Calcium modulation and high calcium permeability of neuronal nicotinic acetylcholine receptors. Neuron 8:127-134.

Vibat CRT, Lasalde JA, McNamee MG, Ochoa ELM (1995) Differential desensitization properties of rat neuronal nicotinic acetylcholine receptor subunit combinations expressed in Xenopus oocytes. Cell Mol Neurobiol 15:411-425.

Wada E, Wada K, Boulter J, Deneris E, Heinemann S, Patrick J, Swanson LW (1989) Distribution of alpha 2, alpha 3, alpha 4, and beta 2 neuronal nicotinic receptor subunit mRNAs in the central nervous system: a hybridization histochemical study in the rat. J Comp Neurol 284:314-355.

Wang F, Gerzanich V, Wells GB, Anand R, Peng X, Keyser K, Lindstrom J (1996) Assembly of human neuronal nicotinic receptor alpha 5 subunits with alpha 3 , beta 2, and beta 4 subunits. J Biol Chem 271:17656-17665.

Whiting P, Lindstrom J (1988) Characterization of bovine and human neuronal nicotinic acetylcholine receptors using monoclonal antibodies. J Neurosci 8:3395-3404.

Whiting PJ, Schoepfer R, Conroy WG, Gore MJ, Keyser KT, Shimasaki S, Esch F, Lindstrom JM (1991) Expression of nicotinic acetylcholine receptor subtypes in brain and retina. Mol Brain Res 10:61-70.

Wong ET, Holstad SG, Mennerick SJ, Hong SE, Zorumski CF, Isenberg KE (1995) Pharmacological and physiological properties of a putative ganglionic nicotinic receptor, alpha 3 beta 4, expressed in transfected eucaryotic cells. Mol Brain Res 28:101-109.

Wonnacott S (1997) Presynaptic nicotinic ACh receptors. Trends Neurosci 20:92-98. 